\title{
Notes on the Copepoda of the North Atlantic Sea and the Faröe Channel.
}

\author{
By
}

R. Norris Wolfenden, M.D., F.Z.S.

(With Plate IX., and one Figure in the text.)

IN a previous notice in this Journal, vol. vi., p. 344, January, 1902, a brief description of the plan of work undertaken by the writer was given. This comprised cruises across the cold-water area of the Faröe Channel during 1900, 1901, and 1902, during the course of which tow-nettings were made at each station with Garstang's net, or Fowler's net, down to 500 to 600 fathoms, simultaneously with hydrographical observations (temperature, collection of water, etc.), which have already been partly reported upon by Mr. H. N. Dickson (Geographical Journal, April, 1903).

The exploration of the Faröe Channel being now, under the International Investigation Scheme, handed over to the Scottish Fishery Board, I have, during 1903, endeavoured to supplement this work by a cruise from Valentia, in Ireland, to the Faröe Banks, crossing in the route the deep Atlantic trough, and keeping almost entirely within the "warm area" of the Atlantic. The first station was located at lat. $51^{\circ} 66^{\prime} \mathrm{N}$., long. $11^{\circ} 21^{\prime} \mathrm{W}$., 120 fathoms, and successive stations at:-

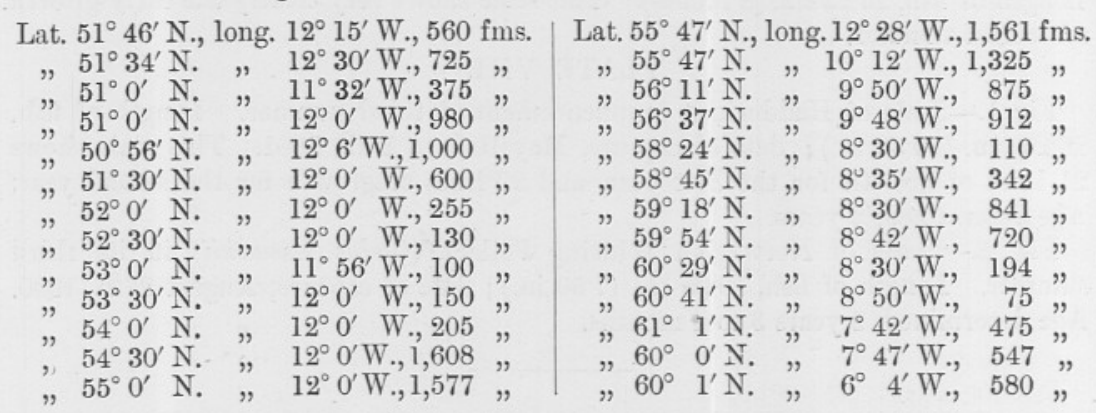

During this cruise was used a new tow-net, devised by the writer and his skipper, Buchan Henry, which has already been exhibited 
by the writer at the "Challenger" Society, and which has been found to work with much greater certainty than either Garstang's net or Fowler's net. The former is too light for very deep-water work, and the latter has frequently been a source of annoyance, but the new net, partly owing to its superior weight and to the extreme neatness and accuracy of the workmanship (manufacturers, Messrs. Bullivant and Co.), was found to work with absolute certainty in the deepest water explored, viz. 1,200 fathoms, until one of the side springs gave way towards the end of the cruise. This was, however, soon replaced.

Altogether on these cruises 216 hauls have been made with closing nets from $0-1,200$ fathoms, 125 vertical hauls, and 89 surface hauls, a total number of 430 hauls. The hydrographical observations made during 1903 have been entrusted to Mr. H. N. Dickson, and will be reported on in due course.

The Pelagic Copepoda collected between lat. $51^{\circ} \mathrm{N}$. and $60^{\circ} \mathrm{N}$. and long. $6^{\circ} 4^{\prime}$ and $12^{\circ} 30^{\prime}$, i.e. west of Valentia and the Faröe Banks, comprise 70 species; those collected in the Faröe Channel, i.e. the cold area, number about 50 species. These therefore give a very fairly complete list of the Copepoda which inhabit the area lying between $51^{\circ} \mathrm{N}$. and $60^{\circ} \mathrm{N}$., lat.

\section{Species occurring in the warm area of the Atlantic $\left(51^{\circ}-60^{\circ} \mathrm{N}.\right)$.}

Calanus finmarchicus (Gunner.).

" tenuicornis (Dana).

Megacalanus (nov. gen.).

Eucalanus elongatus (Dana). , atlanticus (nov. sp.). " crassus (Giesb.).

Rhincalanus nasutus (Giesb.). Paracalanus parvus (Claus). Pseudocalanus elongatus (Boeck).

Spinocalanus abyssalis (Giesb.).

Calocalanus pavo (Dana). magnus (nov. sp.).

Ctenocalanus vanus (Giesb.).

Ftideus tenuirostris (nov, sp.).

Bradyidius armatus (Giesb.).

Gaidius pungens (Giesb.). " major (nov. sp.).

Gaetanus armiger (Giesb.).

, caudani (Canu).

, major (nov. $s p$.).

Undeuchæta major (Giesb.). , minor (Giesb.).

Euchirella carinata (nov. sp.). , curticauda, var. Atlantica.

Euchæta norvegica (Boeck).

, glacialis (Hansen).
Euchæta acuta (Giesb.).

Scolecithrix minor (Brady).

$$
\begin{aligned}
& \text {, } \quad \text { similis (nov. sp.). } \\
& \text {, atlanticus (nov. sp.). }
\end{aligned}
$$

Amallophora magna (Scott).

Lophothrix frontalis (Giesb.). , securifrons (nov. sp.).

Phaenna spinifera (Claus).

Xanthocalanus subagilis (nov. $s p$.).

$$
\text { , } \quad \text { atlanticus (nov. sp.). }
$$

Pseudætideus armatus (nov. sp.).

Faroella multiserrata (nov. gen. et sp.).

Metridia lucens (Boeck).

, Normani (Giesb.).

" brevicauda (Giesb.).

Pleuromamma robusta (Dahl).

Lucicutia grandis (nov. sp.). abdominalis (Lubbock).

$$
\text { " flavicornis (Claus). }
$$

Phyllopus bidentatus (Brady).

Haloptilus acutifrons (Giesb.).

, longicornis (Claus).

Augaptilus magnus (nov. sp.).

$$
\text { , gibbus (nov. sp.). }
$$


Augaptilus longicaudatus (Claus).

Heterorhabdus norvegicus (Boeck).

, longicornis (Giesb.).

, vipera (Giesb.).

, grandis (nov. $s p$.).

, abyssalis.

Anomalocera Patersoni (Templeton).

Egisthus atlanticus (nov. sp.).
Ectinosoma atlantica (Brady and Robertson).

Acartia Clausii (Giesb.).

Candace norvegica (Boeck). , rotunda (nov. sp.).

Oncea sp.

Oithona sp.

Longipedia coronata (Claus).

Paraugaptilus Buchani (nov. gen. et sp.).

\section{Species occurring in the Faröe Channel, cold area.}

Calanus finmarchicus. , hyperboreus.

Eucalanus elongatus. ,$\quad$ atlanticus. " crassus.

Paracalanus parvus.

Ctenoealanus vanus.

Rhincalanus nasutus.

Bradyidius armatus.

Bryaxis brevicornis.

Gaidius pungens. , major.

Gaetanus major.

Chiridius obtusifrons. Vanhöffeni.

Pseudætideus armatus. Faroella multiserrata. Etideus tenuirostris.

Scolecithrix minor. , similis.

Heterorhabdus norvegicus.

Augaptilus zetesios. longicornis.

Euchæta norvegica. , glacialis.

\author{
Euchæta barbata. \\ Pleuromamma robusta. \\ ,$\quad$ abdominalis.
,$\quad$ abyssalis.
}

Lucicutia flavicornis. , magna.

Phaenna spinifera.

Haloptilus longicornis.

Euchirella carinata. , rostrata.

Metridia lucens. , longa.

Egisthus atlanticus.

Candace pectinata.

Temora longicornis.

Centropages hamatus.

Acartia Clausii. typicus.

, longiremis.

, discaudata.

Anomalocera Patersoni.

Oncea sp.

Oithona sp.

Tetragoniceps sp.

\section{A BRIEF DESCRIPTION OF THE NEW GENERA AND SPECIES.*}

1. Megacalanus princeps (nov. gen. et sp.). A huge Copepod was twice taken in the deep water of the Atlantic area, measuring $10 \mathrm{~mm}$. in length, and externally much resembling a Calanus, but differing absolutely in the fact of the last segment of the exopodite of the second, third, and fourth pairs of feet having three marginal spines as well as the terminal saw. The inner margins of the fifth pair have neither denticulations nor hairs. The head is separate from the first segment, and the last two thoracic segments are also separate, the posterior one produced laterally into wing-like ex-

* A full description, with figures of the Copepoda mentioned here, is reserved for a larger work which the writer has had in preparation for the past two years. 
pansions like C. hyperboreus. The anterior antennæ of twenty-five joints are much longer than the whole body. The first pair of feet have an extraordinary double-hooked process on the dorsal surface of the second basal joint, an upper and lower hook placed vertically, the latter very strong and prominent. (PI. IX., figs. 1 and 2.) The structure of the mouth organs is very similar to Calanus. In both cases it was an adult female, with well-developed symmetrical genital segment. The only described Copepod at all resembling it is the C. princeps of Brady (Challenger Report, "Copepoda"), in which the feet are very similar, but there are no such setæ on the anterior footjaws as Brady figures, the maxilla is totally different as regards its bristles, and the segmentation of the anterior antennæ and abdomen is also different. It is therefore certainly not Brady's species. The latter cannot be a Calanus, as is evident from the presence of three external spines on the last segment of the exopodite of the swimming feet.

2. Eucalanus atlanticus (nov. sp.). In the course of dissecting many examples of the well-known $E$. elongatus ð , I have come across a good many specimens which to all outward appearance resemble $E$. elongatus, except that the larger furcal segment, and longest tail seta, are on the left side instead of the right side (Giesbrecht had already noted the irregularity in this respect of the females). But together with this condition the oral organs are not retrograded, as in the $\delta$ elongatus, and resemble entirely those of the female. The exopodite of the posterior antenna is longer; the first joint of the endopodite is not twice as long as the second joint, and is only two and a half times as long as broad; the mandible palp is longer (three times as long as broad), and divided by the origin of the exopodite into two nearly equal parts, and a normal masticatory plate is retained with the usual teeth. (Plate IX., fig. 4.) In the maxilla all the inner lobes are retained as in the $q$, while in $E$. elongatus o they have disappeared. The anterior and posterior footjaws are also normal as in the $q$. The left fifth foot is only a little longer than the right, the first segment of the exopodite of each foot has a short marginal bristle, the last joint of the left side two distal bristles, the right foot three distal bristles. (Pl. IX., fig. 3.) In size $(4.45 \mathrm{~mm}$. to $4.50 \mathrm{~mm}$.) the animal is equal to the adult of of $E$. elongatus.

In various species of Atidiince, while in the last adult stage many males possess fully developed fifth feet together with retrograded oral organs, the stage antecedent to the last is one in which the fifth feet are imperfectly developed, while the oral organs are retained as in the female. This I have proved to be the case in many instances, and the fact accounts for many discrepancies of authors in the description of males with immature fifth feet. I do not know, however, if the

$$
\text { NEW SERIES, - YOL, VII, NO, I, }
$$


peculiarity exists outside of the family Atidiince and extends to the Eucalanidar. Meanwhile, until this is proved to be the case, in which instance the o described above would be only the of $E$. elongatus in the last stage but one, I prefer to regard it as a new species.

3. Gaetanus major (sp. nov.). This has been referred to by the writer in Proc. Zool. Soc., February 3rd, 1903.* It has much resemblance to G. armiger (Gbt.), but is much larger, reaching a size of over $5 \mathrm{~mm}$.; the anterior antennæ are as long, or longer than the body; the lamellar appendage of the posterior foot-jaw is absent, and the exopodites of the first pair of feet are distinctly three-segmented.

The $\approx 4.65 \mathrm{~mm}$. long; cephalic spine short; spines of last thoracic segment short; abdomen of five segments; anterior antennæ twentytwo-jointed (24-25, 8-9, 1-2), nineteenth joint long; oral organs much retrograded; fifth feet very like those of Gaidius major t. The dorsal spine of the head at once distinguishes it as a Gaetanus. (Pl. IX., figs. 7 and 8.)

4. Gaetanus caudani (Canu,? vel nov.). A Gaetanus somewhat resembling G. miles (Gbt.), but the anterior antenna only one and a half times as long as the body; the lamella of the posterior foot-jaw, as in G. miles, not different, as stated by Canu, and the exopodites of the first feet distinctly two-jointed (not three, as in Canu's species); the basal of the fourth feet, like $G$. armiger, i.e. with tubal bristles, and not with spines, as in G. miles (Gbt.). (Pl. IX., figs. 20, 21, and 22).

This may be identical with Canu's $s p$. G. caudani (Ann. Univ. Lyon, v. 26), but if so, the species is subject to variation. His description referred only to a young $\delta$. My specimens, of which there are several, are adult females of a size of $5 \mathrm{~mm}$. and over.

5. Gaidius major $\dagger$ (Wolfenden). A large Gaidius, $4.65 \mathrm{~mm}$. long (and over), more robust than G. pungens (Gbt.), with longer anterior antennæ, shorter spines of the last thoracic segment, three-jointed exopodites of the first feet, and endopodites of the second feet clearly of two joints. It is identical probably with the Chiridius brevispinus of Sars, and his Ch. tenuispinus is almost identical with Giesbrecht's species G. pungens, with which the writer carefully compared it at Naples in April, 1902. N Neither of Sars' species is a Chiridius.

The $\delta$ averages $3.1 \mathrm{~mm}$. long; the head is united with the first segment, there is a one-pointed rostrum; the spines of the last segment are slender; the abdomen, of five segments, only little more than a third of the length of the cephalothorax; anterior antennæ shorter than the thorax, and of twenty-two segments, with long nineteenth

* "The Plankton of the Faröe Channel," No. VIII., G. Herbert Fowler. (Proceed. Zool. Soc., 1903.) † † lbid. † Subsequently referred to. 
joint; the oral parts are retrograded; the first to fourth feet as in the female, the fifth pair rather like Pseudatideus armatus $\delta$, each of two basal joints, and a two-jointed exopodite, right foot the largest, with last segment a curved thin joint ending in recurved spiny process, last joint of the left exopodite spatulate; rudimentary endopodites on each side, the left simple, long, thin, the right short and club-shaped. (Pl. IX., figs. 7 and 8.)

6. Pseudatideus armatus* (nov. gen. et sp.). Resembling Astideus in many features. Strongly bifurcate rostrum in both sexes, last thoracic segments united and produced into short spines. Cephalothorax three times as long as the abdomen; second basal of the posterior foot-jaw three times as long as the endopodite; endopodite of second feet twojointed; simple hairs on the margins of the basals of the fourth feet; anterior antennæ in the $f$ twenty-three-jointed $(8-9,24-25)$; mandibles with exopodite twice as long as endopodite; posterior antennæ with both rami nearly equal. $\delta$ with rostrum; anterior antennæ twenty-two-jointed; oral parts retrograded; a pair of fifth feet, the right foot ending in a curved, spine-like process, the left foot shorter, with broad-haired terminal segment; rudimentary endopodite on each side. Size, f $3.68 \mathrm{~mm}$. ; o a little less. (Pl. IX., figs. 29, 30, and 31.)

This Copepod is identical with Sars' Chiridius armatus $\uparrow$ and Boeck's Euchata armata. It is, however, neither a Chiridius nor a Euchceta, and from its general resemblance to AEtideus I have named the genus Pseudcetideus and the species armatus.

7. Euchirella carinata (Wolfenden). I have previously referred to the $\delta$ of this species found by me in the Faröe Channel (this Journal, vol. vi., p. 366, January, 1902). I have since found adult females in the Atlantic, which confirm the correctness of the previous diagnosis. The female is distinguished by the presence of a median cephalic crest and helmet, a short, strong, one-pointed rostrum, in the proportions of the posterior antennæ (endopodite about half as long as the exopodite and with $8+6$ bristles on the second joint), and the absence of any spinulation of the basals of the fourth feet. In size, $5 \mathrm{~mm}$. (cephalothorax nearly five times as long as the abdomen), this is one of the largest Euchirellas. The bristles of the maxilla are, second basal $=5$, endopodite $=15$.

* Subsequently referred to.

† The genus Chiridius, described by Sars (Crustacea of Norway), contains only one true Chiridius, viz. Ch. obtusifrons. His Ch. tenuispinus and brevispinus are true Gaidius (Giesbrecht), and his Ch. armatus a new genus Pseudcetideus. The modified bristles, large and almost like tubal processes, of the fourth pair of feet, so characteristic of the genus Gaidius, are found in the G. major and pungens (Ch. brevispinus and tenuispinus, Sars) in all my examples and in those kindly sent to me in April, 1902, by Professor Sars, to whom I then pointed out the nature of his species. 
The endopodite of the posterior foot-jaw is only one-third as long as the second basal, which again is very much longer than the first basal (proportions $11: 19: 6$ ). The anterior antennæ are a little longer than the thorax, with the twenty-fifth joint partially divided from the twenty-fourth (eighth coalesced with ninth), and the head is separated by a dorsal line from the first thoracic segment. This Copepod is entirely different from E. pulchra, galatea, or curticauda, especially in the proportions and number of bristles of the posterior antennæ, and the absence of any spines on the first basal of the fourth feet. It occurred at a depth of 400 fathoms, lat. $55^{\circ} 47^{\prime} \mathrm{N}$., and also in the Faröe Channel.

7a. Euchirella curticauda, var. Atlantica. Head with strong crest and helmet, but no rostrum; genital segment very protuberant, and abdomen very short (about one-sixth the length of the cephalothorax); endopodite of posterior foot-jaw only one-half the length of the second basal, the three joints proportionate respectively $10: 13: 6$; posterior antennæ with very slender endopodite, only one-quarter the length of the exopodite, and end joint of the former with only $3+2$ bristles; head separate from the first thoracic segment; maxilla with bristles of second basal and endopodite much reduced $(=6)$. The basals of the fourth feet have only six rather broad-based and long spines, instead of twelve to thirteen, as in $\boldsymbol{E}$. curticauda (Gbt.), and also they differ in some minor particulars. The latter is also a Pacific Ocean species, the Atlantic variety being a little larger $(3.80 \mathrm{~mm}$.) than the Pacific. The Atlantic form is a distinct variety if not a true species, and the widely different habitats suggest specific differences. In the warm area of the Atlantic, lat. $54^{\circ} 30^{\prime} \mathrm{N}$., it occurred at 300 fathoms. Probably the $E$. curticauda of the "Oceana" collections (nine stations from $809-1,710$ fathoms) is this, or the previous species.

8. Atideus tenuirostris (nov. sp.). It is certain that the Etideus armatus of the Faröe Channel and North Atlantic is not identical with that described by Giesbrecht from the Mediterranean, with which I have compared it at Naples. The former has a much less pronounced dorsal cephalic curve; the rostrum is not nearly so strong or so greatly produced, nor does it possess (as Sars has pointed out already) any secondary knobs of chitin at the base of the rostral processes as in the Mediterranean species. In addition the spines of the last thoracic segment are not so long or strong, and the endopodite of the second pair of feet is biarticulate. It therefore seems desirable to distinguish it as a distinct species. Brady's Indian Ocean species (Chall. Report) has not again been met with. I do not find any Aitideus in Mr. 
Gardiner's Maldive collection, nor does Scott mention its occurrence in Professor Herdman's collection of Ceylon Copepoda.

9. Faroella multiserrata (nov. gen. et sp.).* Slender two-pointed rostrum; head fused with first segment, but last two segments of the thorax more or less completely divided, the posterior segment with long lateral spines. Anterior antennæ with eighth and ninth joints fused, but the twenty-fourth distinctly separate from the twenty-fifth. Mandibles with exopodite shorter than the endopodite; posterior foot-jaws with endopodites not more than half the length of the exopodites; first feet with one-jointed endopodites, second pair two-jointed, the terminal saws of the feet distinguished by an extraordinary number of fine and closely-set teeth (69-70). Size of the $q 3.54 \mathrm{~mm}$. and over, the $\delta$ about the same. (Pl. IX., figs. 26, 27, 28.)

It is not uncommon in the deep water of the Faröe Channel, and has been traced by the writer as far south as Valentia in Ireland.

10. Chiridius Vanhöffeni (nov.sp.). One example only of a $\delta$, which I think to be identical with the Pseudocalanus armatus described by Vanhöffen (Grönland Exped., 1891, II. Bd., Berlin, 1897), was taken in the Faröe Channel. Length $3.1 \mathrm{~mm}$; head without rostrum, and last thoracic segment produced into short spines; anterior antennæ of twenty-three joints; posterior antennæ with the outer ramus twice as long as the inner; mandibles with endopodite only half the length of the exopodite, the masticatory plate wanting; anterior foot-jaw almost obsolete, the posterior foot-jaw with the endopodite more than half the length of the second basal; maxilla retrograded, inner lobes nearly obsolete, exopodite large and with ten bristles; first pair of feet with one-jointed endopodite, second pair with two-jointed endopodite; fifth pair of one ramus on each side, each of five segments, the right foot the longest; two short basal and three slender terminal joints, the last ending in a delicate curved stylet process; the left foot with larger basal joints, of the three distal the proximal the largest, the distal short, spatulate, and haired on the inner margin. (Pl. IX., fig. 3.)

In the different segmentation of the feet and in other particulars this Copepod differs from $C h$. obtusifrons, of which it might be the hitherto unknown б. It is certainly not a Pseudocalanus, and though there must always be hesitation about giving an unknown $\delta$ specific rank, it does not agree with any genus except Chiridius, and provisionally, at any rate, must be distinguished from other species.

* This is probably identical with the species described by Sars as AEtidiopsis. His description is, however, rather meagre, and as the writer's descriptions and lithographed plates were prepared for publication two years ago, but have been held over for completion of his monograph, he retains the name originally given to this genus and species. 
11. Candacia rotunda (nov. sp.). This is distinguished from all other Candace species by the fact that the last thoracic segment is rounded on each side instead of being produced into points; the proximal part of the anterior antennæ is of seven joints, the last joint (twenty-fourth) nearly as long as the two preceding joints; the two middle hooks of the anterior foot-jaw of the same length, but shorter than the two end claw bristles. The maxilla, with the second inner lobe, second basal, and endopodite, of about equal length; the third feet with the last exopodite segment denticulated and short end spine slightly bent; fifth feet of three joints, terminal the longest, with three outer short marginal spines, and one inner apical spine long. (Pl. IX., figs. 10,11.)

Size of female, $3 \cdot 2 \mathrm{~mm}$. This is a deep-water species, taken in 300 fathoms in the North Atlantic.

12. Spinocalanus magnus (nov. sp.). Head partially separate from the first segment; genital segment as large as the next two; furcal segments a little longer than the anal; last thoracic segment produced on each side; exopodite of first feet with four inner marginal bristles on the last segment; exopodites of second to fourth pairs with five bristles on the last segment; no fifth feet; joints of the feet very spinulose; anterior antennæ of twenty-four segments, the eighth and ninth fused, the twenty-fourth separate from the twenty-fifth. The characters of the feet clearly distinguish this species as a Spinocalanus, of which it is the largest known species, attaining a size of $275 \mathrm{~mm}$. in the $q$. It was very common in deep water in the Atlantic off the west coast of Ireland.

13. Xanthocalanus subagilis (nov. sp.). Several examples of a Xanthocalanus, taken off the Mull of Galloway by scraping the sandy bottom, resembled $X$. agilis very closely, but the fifth feet of the o differed in length and proportions of the segments and of the three terminal spines from Giesbrecht's species, and the $\delta$ possessed a pair of fifth feet instead of only one as in the Mediterranean species. The right foot of four segments is only a little longer than the left of five segments and a terminal stylet process. The exopodite of the female maxilla has only nine bristles; the endopodite of the anterior foot-jaw has six or seven brush sensory processes and two vermiform processes. A brush process also exists on the first basal of the posterior foot-jaw. The fifth foot of the female has the basal joint the longest and broadest, the margin beset with strong teeth, the second joint with a bunch of hairs at the distal margin, the last joint spinulose on the surface, longer than broad, and the inner marginal spine the largest of the three. o $2.6 \mathrm{~mm}$., o $2.3 \mathrm{~mm}$. The abdomen is not at all setose, as in Giesbrecht's species. (Pl. IX., figs. 17, 32.) 
14. Xanthocalamus atlanticus (nov. sp.). Differs from $X$. agilis and borealis in the characters of the anterior antennæ: very thick basally, tapered distally, and much shorter than the cephalothorax. The first joint of the fifth feet in the $q$ broader than long, with the inner margin armed with closely set spines, the second joint short, the third joint twice as long as broad, with short strong spines marginally, and distally with four broad-based long spines, the inner the longest, the surfaces of all three segments covered with short spines. Size $2.50 \mathrm{~mm}$ Taken on a sandy bottom, at 375 fathoms west of Valentia. Distinguished from $X$. agilis and borealis by the very short anterior antennæ, the fifth feet, and other minor characters. The swimming feet have the segments densely covered with short spines. (Pl. IX., figs. 24, 25, 33.)

15. Xanthocalanus cristatus (nov. sp.). $\quad$ i very large, $5 \cdot 0 \mathrm{~mm}$.; head triangular and with prominent crest; anterior antennæ extending to the end of the furca; anterior foot-jaw with very strong curved hook on the fifth lobe, endopodite of the same with seven short thick brush processes and a long thin curved vermiform process; posterior footjaw with brush sensory process on first basal. Feet as in Xanthocalanus, but fifth pair each of three joints, the first as broad as long, the second longer than broad, the third two and a half times as long as broad, all densely spinulose, with long and short spines intermixed on the surfaces, the last segment with a row of long stout spines on the external surface, and ending distally in two short, rather stout, spiny processes (not articulating spines, as in other species), the innermost a little longer than the outer, and a third similarly formed outer spiny process. (Pl. IX., figs. $18,19$.

No other Xanthocalanus has a crest. Sheaf-like sensory processes as in Amallophora are absent; the segmentation of the feet and of the anterior antennæ, the spinulation of the feet, the separation of the head from the first segment indicate it clearly to be a Xanthocalanus. Taken off the west of Ireland at a depth of 300 fathoms.

16. Scolecithrix similis (nov. sp.). Much resembling S. minor, but the head rounded and oval, the last thoracic segment rounded with rounded flap-like projections; fifth feet one-jointed, twice as long as broad, with very short inner marginal spine inside the apex, and longer spine arising from just below the middle of the inner margin, not as long as the distance between its origin and the apex of the segment. The different shape of the head and corners of the last thoracic segment, and the fifth feet, at once distinguish it from $S$. minor. (Pl. IX., fig. 5, 6.) Size $1.50 \mathrm{~mm}$. Several examples have been taken in the Faröe Channel and the Atlantic. 
17. Scolecithrix atlanticus (nov. sp.). \& very large, $3.95 \mathrm{~mm}$. long. Anterior antennæ twenty-three-jointed and longer than the whole body; rami of posterior antennæ nearly equal; sensory processes of the anterior foot-jaw both brush and vermiform, a brush process on the posterior foot-jaw; fifth pair of feet of two segments, distal the longest, with rounded extremity, and one short stout bristle at the apex, and a thick bristle twice as long arising from the inner margin. Feet like Scolecithrix. There may be doubt whether this species should be considered a Scolecithrix or a Xanthocalanus; the twenty-three-jointed antennæ and coalesced head and first segment are more characteristic of the former genus. It is a very large species, and was taken in 300 fathoms depth off the west coast of Ireland.

18. Lophothrix securifrons (nov. sp.). Head with a strong crest, and strongly pointed wing-like expansions of the last thoracic segment; very short abdomen, with large genital segment, with a downward projecting process in front and strong bunches of lateral hairs. Helmetshaped appendage of head produced anteriorly into a thick rostrum, each ramus ending in a short point. Amalliform (sheaf-like) sensory processes on the anterior foot-jaw, and a similar process on the posterior foot-jaw. Anterior antennæ of twenty-four segments reaching the end of the furca. (Pl. IX., figs. 12, 13, 14, 15.) The animal closely resembles the Scolecithrix securifrons described by Scott (Trans. Linn. Soc.), but differs in the segmentation of the anterior antennæ and in the possession of amalliform sensory processes apparently absent in Scott's species. Size of $q 4.2 \mathrm{~mm}$. Occurred in the warm area of the north Atlantic.

Note,-The sub-family Scolecithrichina is conveniently subdivided into the genera Scolecithrix, Amallophora, and Lophothrix. The characters distinguishing each are as follows :-

1. Scolecithrix. Head usually without crest (only in S. securifrons, Scott); anterior antennæ nineteen to twenty-four jointed ; sensory processes of anterior and posterior footjaws of one kind only (vermiform); fifth feet generally present in the $q$ but always small and of one to three segments; type species $S$. minor (Brady) and $S$. danae (Brady).

2. Amallophora (Scott). Head with crest and helmet-shaped projection; no epistome; anterior antennæ of twenty-two joints; foot-jaws with three kinds of sensory appendages, amallæ, brush processes, and vermiform; maxilla with seven bristles on the exopodite, nine on the endopodite, second basal with four only ; fifth feet of two or three segments, with very long inner bristle; type species Amallophora magna (Scott).

3. Lophothrix (Giesb.). Head with a crest and helmet appendage, produced into rostrum ending in short spines and not filaments; anterior antennæ twenty-four-jointed; maxilla with five bristles on the second basal, eight on the endopodite, nine on the exopodite; sensory processss of the foot-jaws amallæ and vermiform; fifth feet of two or three segments with one to three terminal spines apical and inner, usually strong epistomal projection; type species $L$. frontalis (Giesb.). (Pl. IX., figs. 41, 42.)

19. Heterorhabdus grandis (nov. sp.) (?). The largest known species of Heterorhabdus, attaining a size of $6.60 \mathrm{~mm}$. in length; the anterior 
antennæ longer than the whole body ; the mandibles without long curved teeth; posterior foot-jaw without the long spine; the fifth feet of the $q$ with two stout spines on the surface of the second joint of the exopodite, in the same position as the spines of the same segment in H. longicornis (Gbt.). (Pl. IX., fig. 36.) This may possibly be the same species as the $H$. major of Dahl, of which, however, no description has been published. Only two specimens were captured in deep water in the Atlantic off the west coast of Ireland.

20. Lucicutia grandis (nov. sp.) (?). A $+6.5 \mathrm{~mm}$. long, the largest known species of Lucicutia from the deep water of the Atlantic; the anterior antennæ about four joints longer than the whole body; the genital segment asymmetrical; the first pair of feet with tubular process on the first basal; all the swimming feet, including the fifth pair, with three-jointed exopodites and endopodites. (Pl. IX., figs. 37, 38.) Very pigmented, with deep orange pigment about the mouth, and all organs of the mouth and the feet coloured a shade of burnt sienna. This may be the $q$ of the species described by Giesbrecht from the Pacific, L. grandis, of which, however, he only knew the $\delta$ (6 $\mathrm{mm}$. long).

21. Lucicutia magna (Wolfenden). A single specimen, a o $3.54 \mathrm{~mm}$. long, was found by me in Fowler's Collection from the Faröe Channel. Anterior antennæ longer by one and a half joints than the whole body; the endopodites of the first feet two-jointed; the right fifth foot with a strong spiny process on the inner side of the second basal, and an exopodite of two segments; the rami of the left foot each of three segments. (Pl. IX., fig. 35, 35a.)

21a. Lucicutia atlantica (nov. sp.). i $3.5 \mathrm{~mm}$. long (cephalothorax $2 \cdot 1$, abdomen $1.4 \mathrm{~mm}$.). Head separate from first segment, last two segments fused, and as long as the two preceding. Furcal segments nearly five times as long as broad and as long as the two last abdominal segments. Anterior antennæ longer than the whole body by four segments; rami of the posterior antennæ about equal; the basals and endopodite of the posterior foot-jaws about equal lengths; maxilla resembling $L$. flavicornis, but exopodite larger. First feet with endopodite clearly only two-jointed, the second basal with a marginal tubular process. Second feet with the end saw only one-third of the length of the exopodite last joint. Fifth feet with the end spine only one-half the length of the last exopodite segment, the margin not crenated as in L. flavicornis, the inner marginal thick bristle rather long (nearly two-thirds as long as the last joint of the exopodite) slightly serrated at the distal end. The only Lucicutias with a twojointed endopodite of the first foot are $L$. Clausi and longiserrata. The shape of the head alone distinguishes this species from the former, the 
size and proportions of the saws of the feet from the latter. One example only occurred at a depth of 400 fathoms at station $55^{\circ} 47^{\prime} \mathrm{N}$. It may perhaps be the $f$ of $L$. magna, but is better described, provisionally at least, as a new species.

22. Augaptilus zetesios, Wolfenden. A $q$ which has already been described in this Journal (January, 1902).

23. Augaptilus magnus (nov. sp.). $\& 7 \mathrm{~mm}$. long and over. Anterior antennæ reaching to the end of furca; genital segment larger than the rest of the abdomen; second abdominal segment as long, or a little longer, than the anal segment; furcal segments very short; mandible two-branched; maxilla with seven strong hooks, outer lobe with five, exopodite with only two, second inner lobe with one long hook bristle; both basal joints of the posterior foot-jaw of similar length; endopodite much shorter. Branches of the posterior antenna subequal. Rami of the fifth feet three-segmented.

It has most general resemblance to $A$. megalurus (Gbt.), a Pacific Ocean form, while the furcal segments and shape of the abdomen somewhat resemble $A$. filigerus, but it is nearly twice the size of the latter, and differs in the anatomy of the anterior and posterior antennæ, maxilla, etc. It is a purely deep-water form, found only in the warm area of the Atlantic.

24. Augaptilus gibbus (nov. sp.). The back of the head has a remarkably gibbous swelling. The anterior antennæ are not quite as long as the whole animal. The exopodite of the posterior antenna is not half the length of the endopodite; mandible with two-branched palp; basals and endopodite of posterior foot-jaw equal in length; genital segment longer than the rest of the abdomen; anal longer than the second, and furcal longer than the anal segment; maxilla with outer lobe with three, inner first lobe with six hooks; exopodite with four bristles. Size, $2 \cdot 75 \mathrm{~mm}$.

25. Pseudocyclopia Giesbrechti, Wolfenden. This was described in this Journal (January, 1902).

26. Agisthus atlanticus, Wolfenden. Mentioned in this Journal (January, 1902).

This striking and beautiful little Copepod bears a very close resemblance to AEgisthus mucronatus (Gbt.), but differs in the following points : there is no spine on the third segment of the anterior antennæ; there is a long sensory process on the last joint resembling the sensory process on the third segment (this is the only one present in Eisisth. mucron.); the first feet are clearly three-segmented (two-segmented in Eigisth. muc.); the terminal lance bristle of the fifth foot is only about half the 
length of the foot, and this foot is very clearly three-segmented (in Eg. mucron. one-segmented).

On these grounds I hesitate to regard it as identical with Giesbrecht's species. One specimen was taken in the Faröe Channel (Fowler's Collection), and a second was captured in lat. $50^{\circ} 56^{\prime}$ at 300 fathoms in June, 1903. Giesbrecht's species was a Pacific Ocean one. The EEg. mucronatus recorded from eight stations of the Oceana given by $\mathrm{J}$. C. Thompson is probably identical with my species.

26a. Parangaptilus Buchani (nov. gen. et sp.). $\quad$ \& $325 \mathrm{~mm}$. long (cephalothorax 2.55, abdomen $0 \cdot 7$ ). The head very nuch narrowed in front and general shape like an Augaptilus; two slender rostral filaments very divergent; the abdomen of four distinct segments, the genital very protuberant ventrally and twice as long as the next, which with the middle and anal segment are each of the same size (Pl. IX., fig. 44); the furcal segments not quite twice as long as broad, each with four tail setæ (the longest about as long as the abdomen) and a short dorsal accessory bristle; the last thoracic segment on each side dorsally ends in a short stumpy spine; anterior antennæ of twenty-one joints, the first and second comparatively long, the next nine very short and compressed, the eleventh partly divided from the twelfth, the twentieth from the twenty-first; the left antenna is a little longer than the right, neither of them as long as the whole body; the posterior antenna has the endopodite about twice as long as the exopodite; the mandible is onebranched only, the masticatory plate like Arietellus; the maxilla has the inner lobes much reduced, the second basal and endopodite fused with only three distal bristles, the first inner lobes with five, and exopodite short with two bristles; the anterior foot-jaw is very like that of Arietellus divided into three segments, the first two with small lobes and short bristles, the endopodite short and with very long bristles (eight) provided with augaptiloid cups; posterior foot-jaws with the endopodite as long as the second basal, its segments, five in number, progressively diminishing in size, the first two large; many of its bristles have the augaptiloid cups; the first four pairs of feet have endopodites and exopodites of three segments each; the fifth feet are peculiar, consisting only of a foliaceous plate on each side, imperfectly segmented into two, and carrying each one long marginal and a longer apical bristle. (Pl. IX., fig. 45.)

The animal is an adult with well-formed genital segment; the fourjointed abdomen removes it from the genus Augaptilus; the shape is augaptiloid and not like Arietellus, and the fifth feet are quite peculiar. It seems to partake of some of the characters of each of these genera, but cannot, I think, be referred to either; I attach to it the name of 
my sailing master, to whose constant labour in the management of instruments I owe a great deal.

In addition to the before described new species the following are new :-

27. Heterorhabdus longicornis (Giesb.) 3 . This was described by me in this Journal (vol. vi., 1902) under the name of H.zetesios. Since that time I have taken many specimens in the Faröe Channel and the Atlantic, and have come to the conclusion that it is the $\delta$ of $H$. longicornis, the $q$ of which is of common occurrence in the north Atlantic, and occurs not infrequently in the Faröe Channel. The anterior antennæ are longer than the whole body by four joints, the left a clasping organ of six segments beyond the geniculation; the left furcal segment is much longer and broader than the right. The anterior footjaw has one thick hooked bristle on the fifth lobe, but no tootheomb bristles, and the fifth feet have on the right side an upright and stiff process of the second basal armed with stiff bristles on the inner margin, and the proximal inner margin of the first joint of the exopodite with a protuberance armed with four teeth, and a second smaller protuberance above with a bunch of short hairs. The second basal joint of the foot of the opposite side is armed with short, stiff bristles, the end joint of the exopodite produced into a long curved spine with a shorter marginal spine on the inner side. (Pl. IX., fig. 34.) The mandibles with three teeth on the left side, four teeth on the right masticatory plate.

In the report by I. C. Thompson upon the "Oceana" Copepoda* is figured on Plate VI. a pair of fifth feet of Metridia venusta, which are unlike any known Metridic feet, and resemble those of Heterorhabdus longicornis ${ }^{3}$. The general appearance of the whole animal and the description in the letterpress probably refer to a Heterorhabdus, which the writer had wrongly thought to be a Metridia.

28. Phyllopus bidentatus (Brady). The female of this species is of not uncommon occurrence in the Atlantic west of Ireland. It has been fully described by Giesbrecht. But much uncertainty has existed about the $\delta$. Brady's example was undoubtedly a male. The $\delta$ is $2.25 \mathrm{~mm}$. in length, and closely resembles the o except in the structure of the anterior antennæ and fifth pair of feet. The margins of the last thoracic segment are not in any specimens produced like the figures of Brady (Chall. Rep., "Copepoda"). The abdomen is of five segments, which, with the furcal segments, are of about equal length. The left anterior antenna is of twenty joints, and between the seventeenth and eighteenth is a geniculating joint. Esthetasks are numerous,

"Ann. and Mag. Nat. Hist., vol, xii. Pl. VI. 
and paired at the basal joints. The fifth feet have each a two-jointed basopodite and three-jointed exopodite; the foot of the right side has a rudimentary endopodite, broad and without spines. The second exopodite segment carries two distal hooks; the foot of the other side has a much simpler exopodite, the last joint long and broad distally, without spines. The second basopodite of each side has a long, thin, feathered bristle. (PI. IX., fig. 16.) The Phyllopus bidentatus, figured by I. C. Thompson,* is certainly not identical with my species, if the former is correctly drawn. My Atlantic specimens are, I think, without a doubt the $\delta$ of the species described by Giesbrecht; and the females captured at the same time by me agree entirely with the description and figures of the last-named authority, and not with Brady's. The "bidentate process" does not exist in the Atlantic specimens, and as I have minutely examined quite a dozen, it is not likely that it has been broken off in all of them.

29. Ctenocalanus vanus $\delta$ (nov.). 'On two occasions, once in the Faröe Channel and once in the Atlantic, off the west coast of Ireland, this Copepod has been taken, the $q$ only (described by Giesbrecht) of which is known.

The $\delta$ is $1.25 \mathrm{~mm}$. long; the anterior antennæ of twenty-one joints, the posterior antennæ, with the exopodite, nearly twice as long as the endopodite; the exopodite of the mandible longer than the endopodite, a chitinous remnant of a masticatory plate remaining, but without teeth; anterior foot-jaws retrograded, posterior foot-jaws with the two basal joints of about the same length, the endopodite longer than either; first feet with a one-jointed endopodite, second pair with a two-jointed endopodite, the marginal spines especially of the fourth pair modified, as Giesbrecht has described as characteristic of the species, having peculiarly crenated edges; fifth feet, one long (left) foot of five segments, basal two joints largest and broadest, the distal three joints small, the end one spatulate with bundles of short, stiff bristles on the inner margin; the right side carries a very short stump only, representing the foot. (Pl. IX., fig. 9.)

30. Metridia Normani of (nov.). The only of this species has been described by Giesbrecht; the $q$ has hitherto remained unknown. It is of common occurrence in the Atlantic, west of Ireland.

Length of the $+2.5 \mathrm{~mm}$; anterior antennæ of twenty-five joints, a little longer than the whole body, the first, second, and third with prominent but not recurved spines on the upper margin, that of the third segment the longest, the fifth and sixth segments with shorter spines; both second feet with the usual notch and hook; fifth pair 
of feet, the left longer than the right, of three segments, with three apical bristles, of which the middle is the longest, and a long outer marginal bristle on the second segment; right foot smaller, indistinctly three-segmented, with only two apical bristles of similar length. (Pl. IX., figs. 39,40 .)

The genital segment is not so long as the next two; the furca is longer than the anal, nearly four times as long as broad, and asymmetrical, that of the right side shorter than the left. This Copepod was frequently found in company with undoubted $\delta$ examples of Met. Normani.

Dichotomous branching of tail setce. A curious condition was first observed by me in many instances amongst the Copepoda (referred to me by my friend Mr. Stanley Gardiner) from the Maldive Islands of the Indian Ocean. This consisted of a branching and sub-branching of the setæo of the tail, an attempt at dichotomous division, so that in many instances the whole of the tail setæ were converted into a sort of brush. I had never observed this in any Copepoda from our more northern regions, and looked upon it as a condition probably peculiar to the Copepoda of the Maldive region; but I have lately observed exactly the same in two examples from the Atlantic taken west of Valentia, in Ireland, viz. once in Undeuchceta major and once in Euchceta norvegica. In the Maldive seas it has occurred with great frequency in Calamus vulgaris, and also in Calocalanus, Paracalanus aculeatus, Scolecithrix Danae, Euchirella bella. It will be observed that it is always in the Amphaskandria that this condition occurs. In the Maldive Collection it is of such frequent occurrence that it suggests a special variety in each instance. What the precise significance may be I do not know, possibly a device to assist flotation, but it is curious that it should occur also in examples from the North Atlantic. The dichotomous branching is very irregular, sometimes of one seta only, or two, or all the setæ of one side only, or of both sides.

\section{Remarks on the Horizontal Distribution of the Copepoda.}

Calanus finmarchicus. Sars (Crustacea of Norway) has recently endeavoured to distinguish the Northern and Polar form under the name of $C$. finmarchicus from a southern form C. helgolandicus, basing his opinion upon the size, length of the antennæ, shape of the head, and structure of the fifth feet. I have very carefully compared examples from Thorshaven, the cold area of the Faröe Channel, the warm area of the Atlantic, and the English Channel, and I am of opinion that the factors upon which Sars bases this distinction are too inconstant to admit such a separation into specific forms. Examples from the 
southern waters are met with in which the shape of the head and the size of the animal, length of antennæ, etc., are in no wise different from the northern species. The structure of the fifth feet of the $\delta$ is known to vary very considerably, as Giesbrecht long ago pointed out for examples from Hong Kong. Even in Faröe examples (and those from more southerly latitudes) this is also the case, and the fact is that the species is very variable. Being also the most prolific Copepod known, at any rate in northern waters, and constantly present in various stages of development, is it not more natural to regard these variations as only different stages of growth? At any rate, the very careful measurements and study which I have made of this Copepod between the lat. $51^{\circ}-62^{\circ} \mathrm{N}$. convince me that the points stated by Sars are not sufficiently reliable to justify such a differentiation of the species. The horizontal distribution of this Copepod is known to be very wide. In the Faröe Channel it is extraordinarily abundant, but south of the Wyville-Thompson ridge it appears to get less frequent the further south we go, and though taken throughout the Atlantic traverse, it does not occur in great numbers at about lat. $51^{\circ}$ (at any rate in 1903). It is, however, known to reach the deep water under the Sargasso Sea (Dahl).

Eucalanus. In a former list (this Journal, January, 1902) I included Euc. attenuatus in the list of Copepoda found in the Faröe Channel. It is true that I found it once in a sample from Station A 1 in the Faröe Channel, but I am of opinion now that this sample had become contaminated with some material from the Indian Ocean, and as I have never found it in any other samples from the Faröe Channel, including those collected by Fowler, which were afterwards referred to me, I must conclude that it does not occur in the Faröe Channel. In a subsequent paper by Dr. Fowler in Proc. Zool. Soc., February 3rd, 1903, it is spoken of as forming 22 per cent. of the Epiplankton and 41 per cent. of the Mesoplankton of this region. This, however, is an error, and it should be eliminated from the list. The species referred to is undoubtedly $E$. elongatus. This species is very abundant in the Faröe Channel, not uncommon in the fiords of Shetland, and occurs throughout the Atlantic stations as far south as $51^{\circ}$, but less abundantly than in the Faröe Channel, where it is apparently indifferent to temperature, occurring at all depths. It is, however, curious that it does not extend further north to the Norwegian Sea, and is not mentioned by Sars as having been seen off the Norwegian coast. Its northern limitation appears to be very well defined.

Euc. crassus is frequently met with in the Faröe Channel, and has occurred in great abundance in some hauls with the "midwater open net" at 45 to 50 fathoms. It is also met with throughout the Atlantic 
stations, and is very common in Mr. Gardiner's Maldive Collections, thus appearing to thrive under widely differing conditions as to temperature, etc. Its northward and eastern extension appears to be as well defined as that of the previous species, as it is not mentioned by Sars.

Rhincalanus. The Rhincalanus cornutus, also included in the list before mentioned, must be removed for the same reasons as $E$. attenuatus. It never occurs in the Faröe Channel, and I have never yet found it in the Atlantic north of $51^{\circ}$. lat. In Fowler's list (P.Z.S., June 21st, 1898) it is recorded as frequent, especially in the Mesoplankton. In Fowler's collection it was certainly absent, but Rhinc. nasutus was common, and, in fact, is scarcely ever absent from the Epi- or Meso- plankton of this region, and it is evident that the two species have been confused. $R$. cornutus is distinctly a southern ocean form, and all records of its oceurrence beyond $30^{\circ} \mathrm{N}$. must be looked upon with suspicion. Rhinc. nasutus occurs often in great abundance in the Faröe Channel, and frequently throughout the Atlantic traverse. I have found it in the Maldive Collection, but very sparingly, and Scott mentions it among the Ceylon Copepods. Like Eucalanus, its northern distribution is apparently well defined, having occurred only at two stations of the cruise of the Michael Sars, in deep water off the coast of Iceland, and once in the North Sea between Scotland and Norway.

Pleuromamma. Pl.abdominalis is not common in the Faröe Channel, while $P l$. robusta (Dahl) occurs with great frequency. Consequently the records of $\mathrm{Pl}$. abdominalis in Fowler's list (loc. cit.), and the figures ( 5 per cent. Epiplankton and 58 per cent. Mesoplankton) in his second paper (February 3rd, 1903) must be doubted. Pleur. robusta occurred abundantly in Fowler's collection, and in my own Faröe collections it is the common Pleuromamma of the Faröe Channel and North Atlantic ( $51^{\circ}$ to $62^{\circ} \mathrm{N}$.). Though Pl. abdominalis does occur in the North Atlantic, it is comparatively rare in my collections.

The distribution of this Copepod ( $P l$. robusta) is not unlike that of Eucalanus and Rhincalanus. Sars mentions the occurrence of a few specimens "somewhat north of the Faröe Islands," and two specimens only from Norway. It occurred throughout my Atlantic traverse in 1903 , and for four years successively has been always abundant in the Faröe Channel, but north and east of Shetland it appears to have a fairly well defined limit, though apparently reaching, in small numbers, the coast of Norway. Pl. abdominalis was not common in the Atlantic traverse. Pl. abyssalis has occurred in my experience only once in the Faröe Channel.

Euchirella. Only two species of Euchirella occur in the Faröe Channel, viz. E. rostrata and E. carinata. The former is of frequent 
occurrence. What was meant by $E$. pulchra (frequent at 450 to 320 fathoms) in Fowler's list (P.Z.S., June 21st, 1898) I do not know, but I am pretty confident that it was not E. pulchra, and probably was $E$. rostrata. I found the latter species in Fowler's collection, and I have taken it several times since, but it has not occurred in my collections in the Atlantic south of the Wyville-Thompson ridge, being there replaced by a variety of $E$. curticauda. $E$. rostrata does not apparently occur in the Norwegian Sea, but it is recorded by Scott in the Ceylon Copepoda. In the neighbouring Maldive Islands, however, I have not met with it, but only $E$. bella. That it should occur at such widely different localities is not a little curious. The limitation previously given by Giesbrecht ( $F . u . F l . N$.) was $44^{\circ} \mathrm{N}$. to $41^{\circ} \mathrm{S}$.

Paracalanus parvus. Found plentifully in Christiana Fjord by Sars, and South Norway, though not apparently further north, none having been observed at Bergen by Nordgaard, nor in the Plankton samples from the Northern Ocean examined by G. O. Sars (Sars' Crust. Norway, p. 18), and common round the British coasts. It occurs in the Faröe Channel, and as far south, at any rate, as lat. $51^{\circ}$ (Valentia in Ireland); occasional in deep-water samples, it is not common in the open ocean. It has probably not such a wide southern distribution as has been imagined. Met with in the Indian Ocean and Mediterranean, I think there is reason to differentiate the two forms, boreal and Mediterranean (and Indian Ocean), as at least distinct varieties. A careful examination of the figures of this species given by Sars (Crust. Norway) and Giesbrecht ( $F$. u. Fl. Golfes Neapel) discloses differences, and I have made a detailed examination of examples from the Faröe Channel and from the Indian Ocean (Maldives) for the purpose of comparison.

The Southern Ocean examples are found constantly to be rather smaller than the northern, the basal joints of the feet are more densely armed with short spines (in the northern variety these are almost entirely absent, especially on the fourth pair), the basal joints and the last segment of the exopodites (fourth pair) are broader in proportion to the length (exopodite 3 is five times as long as broad in the boreal variety, only four as long as broad in the Indian variety), and the anterior antennæ are rather longer in proportion to the body in the southern variety. On the whole the southern variety may be said to be constantly smaller, more spiny, and with less attenuated segments of the feet (in which the marginal teeth are also stronger and coarser) than the northern. This difference is also noted in comparing the figures of Giesbrecht's $P$. parvus from the Mediterranean with those of Sars' $P$. parvus from Norway. They are not distinct species, but undoubted varieties, and the northern form, though extending as far south as lat. $51^{\circ}$ (Valentia), does not probNEW SERIES, - YOL, VII, NO, 1 , 
ably reach the Mediterranean, from which point southwards the southern variety extends. The species described by Scott as $P$. parvus from the Gulf of Guinea must, I think, be designated $P$. aculeatus (Gbt.).

Calocalanus pavo. The occurrence of this species north of $50^{\circ} \mathrm{N}$. is unusual, its previous limitation being $30^{\circ} \mathrm{N}$. Two undoubted examples occurred in hauls made west of Valentia, but in this case it was probably an accidental wandering beyond its proper limitations.

Ctenocalanus vanus and Calanus tenuicornis must probably be regarded as having wandered far out of their usual habitat when found, the former in the Faröe Channel, the latter off the west coast of Ireland. The former is recorded, however, by Giesbrecht as rather common in the Antarctic Ocean (Voy. du Belgica).

Heterorhabdus. The species which I had previously named H. Clausii (this Journal, January, 1902) should be $H$. norvegicus. Until the publication of Sars' recent work (Crust. of Norway) no full account, and no figures of the original species of Boeck were available. I am now convinced that the Faröe examples are really Boeck's species, $H$. norvegicus, which extends southwards at any rate to $52^{\circ} \mathrm{N}$.

The $H$. zetesios recorded in that list I now think to be the male of H. longicornis, previously unknown, and I have taken it on many occasions since that date, both in the Faröe Channel and the Atlantic.

$H$. norvegicus is distinctly a boreal species, while $H$. longicornis (vel zetesios) belongs just as certainly to the warm area, occurring with considerable frequency in the warm Atlantic area. The $\delta$ is of such frequent occurrence in this region that it is curious that it should have been overlooked in previous records. $H$. vipera and $H$. abyssalis occurred only in the warm area, and have never been seen north of the Wyville-Thompson ridge. $H$. grandis is certainly only a very deep water species.

The Heterorhabidce are species which seek deep water and do not approach the coasts, at any rate in the North Atlantic. H. norvegicus is capable of existence within a very extreme range of temperature, from the polar water of the Faröe Channel to the warm Atlantic. $H$. longicornis can apparently endure greater extremes than $H$. vipera, but is not so robust as the first-named species. Amongst Epiplankton I have found only quite young and undeveloped examples of Heterorhabdus.

Candace. What is meant by Candace truncata in Fowler's list (P.Z.S., June, 1898) it is impossible to say. It is a Pacific Ocean species. Probably Thompson meant C. norvegica (Boeck), which has received a full description from Sars (in Crustacea of Norway) and extends southwards, at any rate as far as $51^{\circ} \mathrm{N}$., where I took it at a depth of 300 fathoms. 
Chiridius. In 1892 Giesbrecht established this genus for a Copepod (Ch. poppei) of small size $(1.8 \mathrm{~mm}$.), which was characterised by the absence of rostrum and the very short endopodites of posterior antennæ and mandible.

Sars has extended the genus by the inclusion of four species - Ch. armata, Ch. brevispinus, Ch. tenuispinus, and Ch. obtusifrons. There can, however, be no doubt that brevispinus and tenuispinus are really examples of Giesbrecht's genus Gaidius. In both occur the modified tubal bristles of the basal joint of the fourth feet, which Giesbrecht remarked long ago to be midway between the ordinary bristles of AEtideus and the spines and teeth of Euchirella. Chiridius tenuispinus (Sars) is identical with Gaidius borealis (described by me in this Journal, January, 1902), and Chiridius brevispinus (Sars) is identical with the species which I had previously named Gaidius major.

Chiridius armatus (Sars), owing to its possession of a two-pointed rostrum, is clearly not a Chiridius, and from its close resemblance to AEtideus was, two years ago, placed by me in another genus to which I gave the name Pseudactideus. (See Report of the Brit. Assoc., the Zoological Station at Naples, 1902.)

Consequently only one of Sars' species, viz. Chividius obtusifrons remains to be included in the genus Chiridius, which now includes only Ch. poppei (Gbt.) and Ch. obtusifrons (Sars). The latter form, which appears to have been abundant in the Polar basin in Nansen's Expedition (Sars, loc. cit.), occurs also, though not commonly, in the Faröe Channel, and my examples agree entirely with the description given by Sars.

It may be doubted if the Gaidius pungens of Giesbrecht is really identical with the Faröe Channel and North Atlantic forms, for in the former the second pair of feet have a one-jointed endopodite, while in the latter it is distinctly two-jointed, added to which must be considered the widely different localities of habitat, which would at once lead to a supposition of non-identity. (Pl. IX., fig. 43.)

$$
\text { G. pungens (Giesbrecht). }
$$

Exopodite of first foot two segments.

Endopodite of second foot one segment.

Spiny prolongation of last segment shorter than in borealis. Size, \& $3.2 \mathrm{~mm}$. (Pacific Ocean).

G. borealis (Wolfenden), Ch. tenuispinus and G. tenuispinus (Sars).

Exopodite of first foot indistinctly three segments.

Endopodite of second foot two segments.

Spiny prolongation of last segment longer than pungens,

Size, o $3.8 \mathrm{~mm}$. (North Atlantic). 
In addition there are minor differences in the relative proportions of the segments of the feet, number of teeth on the terminal saws, hooked bristles of the anterior foot-jaws, proportions and length of the segments of the posterior foot-jaws (first and second basals shorter and broader).

The differences, though small, along with the widely different habitats, cause me to hesitate before regarding them as identical, and probably they are varieties.

Gaetanus. Of the two species of Gaetanus (armiger and major) which I find common in the Atlantic, and somewhat more uncommon in the Faröe Channel, the doubt may be expressed (as in the case of Gaidius) whether the species G. armiger is really identical with Giesbrecht's Pacific Ocean examples. Specimens from the Atlantic clearly have the modified tubal bristles on the basal of the fourth feet (apparently absent in Giesbrecht's species), and are larger than Giesbrecht's species (viz. $4.4 \mathrm{~mm}$., as compared with $3.2 \mathrm{~mm}$.), but otherwise the resemblance is very great. However, combined with such widely different habitat, it might be considered advisable to regard them as different species, in which case our northern species might be distinguished as $G$. atlanticus. No doubt can be entertained in the case of Gaetanus caudani that it is not identical with $G$. miles (Gbt.), though doubt may be felt whether the specimen described by Canu (Ann. Univ. Lyon, vol. xxvi.) is identical with the North Atlantic examples; but as this appears to have been an immature male, a proper comparison can scarcely be made.

With regard to the horizontal distribution of the genera Gaidius and Gaetanus, Gaidius is of constant occurrence in the deep water only of the Faröe Channel, and though it wanders south into the warm Atlantic, it is by no means of such frequent occurrence as further north. Gaidius major, and to a less degree G. pungens, are in the North Atlantic distinctly boreal species, occurring with frequency in the Polar seas (Sars). Chiridius obtusifrons seems at present to be still more markedly a Polar species, occurring sparingly in the cold under-water of the Faröe Channel, and Pseudatideus armatus has the same distribution as Gaidius. Both can be traced down as far as lat. $51^{\circ} \mathrm{N}$., possibly further south.

Gaetanus species, on the contrary, appear to be of more a warm Atlantic area habitat. Their frequency diminishes going northwards, and Gaetanus is not mentioned in Sars' lists. G. major alone passes into the Faröe Channel, G. armiger and caudani not appearing north of the Wyville-Thompson ridge, though on one occasion I took an undeveloped example (? G. miles vel caudani) just south of this locality.

Euchceta. E. marina, described in Fowler's paper as common at various depths, is erroneous.* It does not occur in the Faröe Channel, nor have I found it in the North Atlantic, at any rate as far south as

\footnotetext{
* Its inclusion in my list (this Journal, January, 1902) was also an error.
} 
$51^{\circ} \mathrm{N}$. Two species, $E$. norvegica and barbata, are common; the third, E. glacialis, is rather rare. The first species occurs in so many stages of development that Thompson, who reported upon Fowler's Copepoda, was probably misled. Though doubt has been expressed upon the accuracy of the diagnosis of $E$. barbata, there is no doubt that this is ${ }^{*}$ a good species. Each of the three differs, especially in the form of the genital segment of the female, the length of the appendicular tail setx, the structure of the first and second feet, and the anatomy of the last segment of the fifth foot of the ð, especially in its "scissors" arrangement. What is meant in Thompson's list by E. hessii and E. gigas (Brady) it is difficult to say: At any rate only the three Euchoetas mentioned are as yet known to occur in the Faröe Channel.

$E$. norvegica extends southwards into the warm Atlantic area, at any rate, as far south as $51^{\circ} \mathrm{N}$. It is fairly common in the warm area, but not so much so as in the deep water of the Faröe Channel, where it is seldom absent from deep hauls; it is thus capable of ranging through wide differences of temperature. Though, as I am informed by Sir J. Murray, it is of common occurrence in the surface waters of some of the Western Scotch lochs, I have never seen an adult in the surface area of the Faröe Channel or Atlantic. Young and undeveloped specimens are not uncommon near the surface, but the adult animal appears to prefer the deep water down to 500 to 600 fathoms, and to extend northwards to the Polar basin.

E. glacialis, observed abundantly in the Polar basin (Hansen), but seldom in the Norwegian Sea, is of rare occurrence in the Faröe Channel, and once only it occurred in the warm Atlantic area.

$E$. acuta, of which a few undoubted examples were met with in lat. $50^{\circ} 56^{\prime}$ and $12^{\circ} 6^{\prime} \mathrm{W}$. long. at 300 fathoms depth, has hitherto had a northern limit of only $41^{\circ} \mathrm{N}$. It has lately been recorded by Scott from the Indian Ocean.

E. barbata, first described by Brady from the South Atlantic (Rio Janeiro), and lately by Scott from Ceylon, occurring with frequency in the Faröe Channel, has thus a very wide range. In the Atlantic it is purely a deep-water species, occurring once at 500 fathoms in lat. $55^{\circ}$ $47^{\prime} \mathrm{N}$.

These three species ( $E$. norvegica, glacialis, barbata) may be distinguished from each other by the following points (cf. Fig. 1 in text):-

$E$. norvegica, + . The last thoracic segment on each side ending in a blunt spine. The genital segment with genital swelling occupying the lower part of the segment, the opening nearly round, guarded on each side by a prominent blunt tubercle. Second foot: the external spine of exopodite 2 does not reach the end of the first marginal spine of exopodite 3 , the second spine of exopodite 3 does not nearly reach the 
end of the segment. First foot: exopodite 1, with partial division into two segments, margin very concave above and convex below, with a marginal bristle not reaching the end of the segment. Appendicular bristle of the tail very long. Colour greenish yellow; about $8 \mathrm{~mm}$. long.

$E$. glacialis. The last thoracic segment rounded and without tip. Genital segment very prominent with conical swelling; genital orifice guarded on each side by an upper and lower tubercle, and opening oval

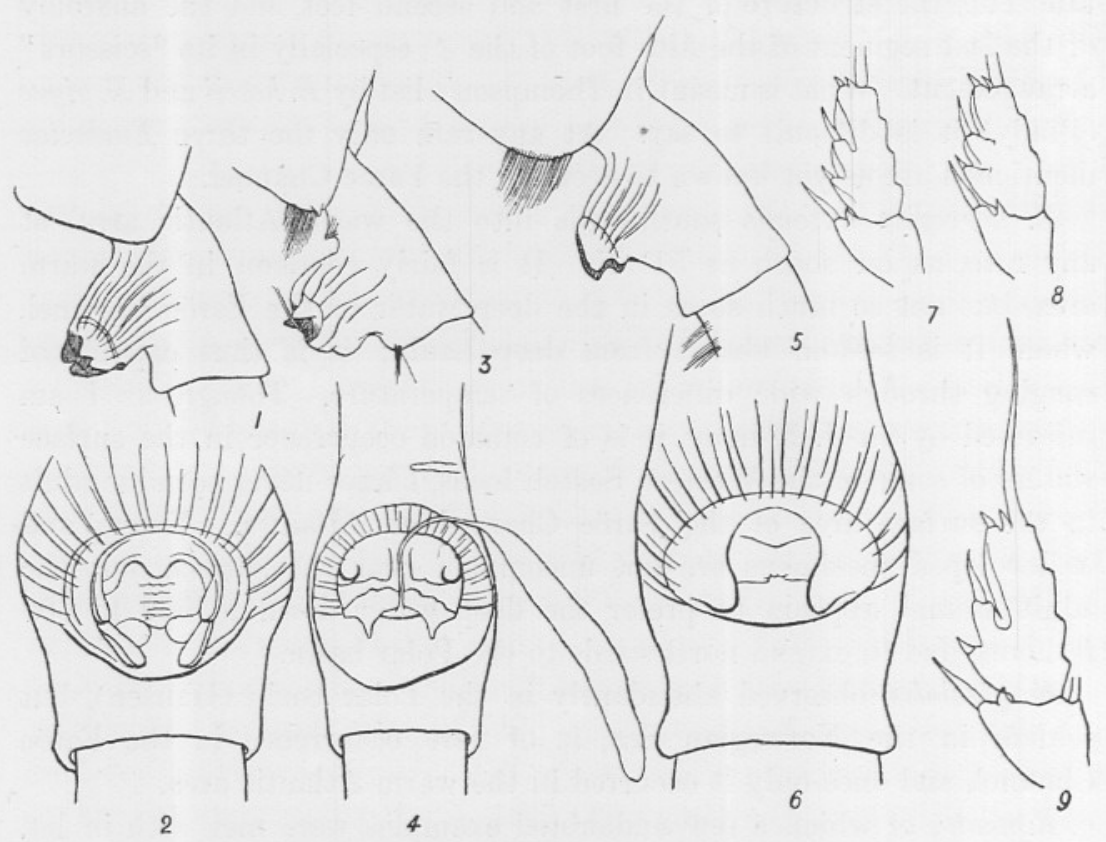

Fig. 1. Comparison of three species of Euchæta.

1. Euchata"glacialis.

2. ", " Genital segment, ventral surface.

3. ", norvegica.

4. , ,, Genital segment, ventral surface.

5. ", barbata.

6. , ,,$\quad$ Genital segment, ventral surface.

7. Last two segments of exopodite of second feet of Euch. glacialis.

$8 . \quad, \quad, \quad, \quad, \quad$ Euch, norvegica.

9. ",

(broader than long); the genital swelling occupies more the middle of the segment, which is much swollen laterally. Second foot, with the marginal spine of exopodite 1 very large, reaching the tip of the first spine of exopodite 2; the second marginal spine of exopodite 3 larger than in $E$. norvegica and reaching the end of the segment. First foot without trace of segmentation in the exopodite 1 and its marginal seta very small. Appendicular bristle very short. Colour greenish yellow, 
with a quantity of red pigment diffused, especially about the mouth organs; size, about $10 \mathrm{~mm}$.

E. barbata. Last thoracic segment rounded on each side. Genital segment not so swollen as the other two species, swelling occupying the middle of the segment, more protuberant above than below; genital orifice oval, broader than long, guarded by lateral lamellar swelling on each side. Second foot, with marginal spine of exopodite 1 stout and reaching the end of the first spine of exopodite 3 ; second spine of exopodite 3 not reaching the end of the segment. First foot, with exopodite distinctly segmented into 3. Appendicular bristle long. Colour always bright red, feet and mouth organs coloured red; size, 10-11 mm. ; very hirsute.

Haloptilus. H. acutifrons (Gbt.), recorded by Sars once from the Polar Sea and once from the Norwegian Sea, occurred twice only in the Atlantic townettings. H. longicornis, recorded by Sars once only from a station between Finmark and Bear Island, was captured several times in the North Atlantic, and once only in the Faröe Channel cold area.

Neither of these species can be regarded as indigenous to the north cold ocean. Their distribution is pronouncedly southern, and H. longicornis extends from the Mediterranean to the Indian Ocean, where it is very common round the Maldive Islands.

Augaptilus. The occurrence of several members of this genus in the North Atlantic is interesting. Only one of them am I able to thoroughly identify with any species described in the list of Giesbrecht and Schmeil (Das Tierreich, "Copepoda"), only three of which, by the way, are European, four being Pacific Ocean species, and one recorded only from the Gulf of Guinea.

The description of Augaptilus glacialis (Sars), said by this authority to be a Polar species, is not at the moment of writing available to me. The 3 briefly described by I. C. Thompson is in all probability not this species at all, the size given by Thompson,** $4 \mathrm{~mm}$., being greatly in excess of that of $A$. palumboi (Gbt.), viz. $2 \cdot 25 \mathrm{~mm}$. $q$, and no truly Pacific Ocean $\uparrow$ forms have yet been recorded from the North Atlantic. While the three species taken by Scott in the Gulf of Guinea appear to be as much epiplanktonic as mesoplanktonic (25-360 fathoms), in the "Oceana" report the Augaptilus species appear to be only mesoplanktonic, all being captured at 1,000 fathoms or under. In the North Atlantic none of my species appeared above 300 fathoms. Two of them are new, and only one, A. longicaudatus (Claus) has a wide range (Mediterranean, Gulf of Guinea, and Pacific Ocean).

* “ 'Oceana' Copepoda," Ann. and Mag. Nat. Hist., vol. xii.

† Augap. palumboi, bullifer, megalurus. 
Lucicutia species show a distribution similar to other warm-water species, and may be regarded as wandering into the Faröe Channel by accident. L. flavicornis is not often found there, but increases in frequency further south of the Wyville-Thompson ridge. It has a very extensive range, occurring with frequency about the Maldive Islands of the Indian Ocean.

Metridia species. M. longa is clearly a distinctly northern form, occurring with great frequency in the deep water of the Faröe Channel, and at very low temperatures, and is traced down the North Atlantic, where it occurs with much less frequency and in deep water. M. lucens, on the contrary, is apparently very common in the warm area of the Atlantic; equally with the cold area of the Faröe Channel, at any rate as far south as lat. $50^{\circ} \mathrm{N}$., south of which, however, it appears only doubtfully to reach.

M. Normani, which was described by Giesbrecht from the Faröe Channel, has not occurred in any of my collections in that region for the last four years, but was common in the North Atlantic during the summer of 1903 , especially between lat. $50^{\circ}$ and $55^{\circ}$; its presence in the Faröe Channel at any time is therefore probably accidental.

M. brevicauda, of which several examples occurred off the Irish coast in 1903, has hitherto been regarded entirely as a Pacific Ocean species (Giesbrecht). M. longa, and especially $M$. lucens, may be regarded as typical northern cold-area forms.

Oncea species (especially 0 . conifer $a$ ) are rarely absent from any townetting in the Faröe Channel or North Atlantic in deep water; they are very rarely, however, found at the surface. The genus is cosmopolitan and has representatives.in the Indian Ocean nearly as abundantly as the northern seas. The same may be said of Oithona, especially 0. plumifera and similis, and both Oncea conifera and Oithona similis are recorded by Giesbrecht from the Antarctic Ocean (Voyage du S.Y. Belgica, 1902). The same may be said of Microsetella atlantica, common throughout the Faröe Channel, the North Atlantic, less common in the Indian Ocean (Maldives, Wolfenden), Ceylon (Scott), and in the Antarctic Ocean (Giesbrecht loc. cit.). Bradyidius armatus is similarly cosmopolitan, frequent in the Faröe Channel, round the British Isles, occurring also in the Mediterranean, and round the Maldive Islands of the Indian Ocean. Acartia Clausii is similarly cosmopolitan, and along with Oncea conifera, Oithona plumifera and similis, and Ectinosoma (Microsetella) atlantica, indifferent to depth and temperature. Scolecithrix minor is also widely distributed, very common in the Faröe Channel, but less common in the North Atlantic.

Amallophora magna occurred with frequency in the warm Atlantic area, especially about lat. $51^{\circ}$ to $52^{\circ} \mathrm{N}$., in the summer of 1903 . Scott 
has described it from the Gulf of Guinea, and Sars states that it was abundant in the Polar basin crossed by Nansen; it is recorded by Giesbrecht from the Pacific, near Bergen (Nordgaard), and "at some distance north of the Shetland Isles" (Sars). I have never once found it in the Faröe Channel. Considering its widely differing habitats, it is not easy to see why it should be described by Sars (Crust. Norway, p. 53 ) as of "undoubtedly Arctic origin." An allied species, A. brevicornis, is recorded by Scott once from a locality east of the Shetland Isles. The same Copepod occurred in the cold area in July, 1902, but differs from Sars' description in the entire absence of amalliforus sensory processes, which are replaced by strong brush processes on both maxillipedes. The head is broad and entirely without crest, and in every other respect it agrees with Sars' A. brevicornis, but cannot be an Amallophora.

In considering the horizontal distribution of the Copepoda of this region, the following occur with frequency, and may be said to be indigenous to the Faröe Channel:-

Calanus finmarchicus, Eucalanus elongatus and crassus, Rhincalanus nasutus, Paracalanus parvus, Pseudocalanus elongatus, Etideus tenuirostris, Gaidius pungens and major, Gaetanus major, Euchæta norvegica, barbata, and glacialis, Pseudætideus armatus, Faroella multiserrata, Metridia lucens and longa, Pleuromamma robusta, Heterorhabdus norvegicus, Ectinosoma atlantica, Acartia Clausii, Candace pectinata, Oncea conifera, Oithona similis, Centropages typicus and hamatus, Euchirella rostrata, Bryaxis brevicornis, Scolecithrix minor and similis, Bradyidius armatus.

Others in the foregoing list, which occur only occasionally, are visitors brought from the Norwegian Sea or from the Atlantic south of the Wyville-Thompson ridge, such as Phaenna, Haloptilus, Chiridius obtusifrons, Ctenocalanus, Augaptilus, Pleuromamma abdominalis, Lucicutia, Anomalocera, Egisthus.

I have not been able to state any essential differences as to abundance of these individual species during the years 1899-1903, though the hydrographical conditions of the Channel have been widely different.* Thus in 1900 the whole Channel was occupied by water coming from the south, strong earlier in the season, but in July with little movement, but indications of intrusion of northern water at a depth of 300 fathoms on the east side. In 1901 most of the Channel was occupied by water from the south, with feeble southward movement in the depth. In 1902, at all depths below 150 fathoms, the Channel was filled with unusually cold fresher water, the southward movement increasing both

* See Mr. H. N. Dickson's report ("Hydrography of the Faröe-Shetland Channel," Geographical Journal, April, 1903) upon the hydrographical results of the author's cruises in this region. 
at the surface and deep as the season progressed, driving out the waters of southern origin. This was an exceptional year.

The physical conditions in the Faröe Channel are, as is well known, widely different from those existing in the neighbouring Atlantic, and in this area we have a very mixed fauna, but it is not difficult to determine which species of Copepoda are, so to say, indigenous to this area. In the tables appended the species captured at each station in the 1903 cruise are tabulated. I purposely leave out the consideration of the observations made exclusively in the Faröe Channel in the three preceding years for future consideration. Only three stations in the "cold-water area" (F. VII., VIII., IX.) were visited in 1903, but they serve for comparison with those on the southern side of the WyvilleThompson ridge.

Throughout the cruise there was a remarkable paucity of Copepoda at the surface as far as species are concerned, and the well-known fact is again established that the nearer the cold ocean is approached the smaller the number of species, but the greater the abundance of individuals of the same species. Thus between $51^{\circ}$ and $52^{\circ} \mathrm{N}$., thirteen species occurred at the surface; at no station north of this were there more than six species found.

Between lat. $51^{\circ}$ and $52^{\circ} \mathrm{N}$. there occurred at

\begin{tabular}{|c|c|c|c|}
\hline 100 & " & 14 & , \\
\hline 200 & " & 22 & , \\
\hline 300 & ", & 28 & , \\
\hline 400 & " & 24 & 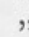 \\
\hline
\end{tabular}

$\begin{array}{rrrr}500 \text { fathoms, } & 18 \text { species. } \\ 600 \quad & 13 & , \\ 700 & " & 10 & , \\ 800 \quad & 15 & , \\ 1,000 & , & 5 & ,\end{array}$

Between $52^{\circ}$ and $54^{\circ} \mathrm{N}$. there occurred at

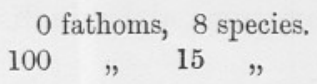

150 fathoms, 12 species. $100 " 15 \%$ 250 " 6 ,

Between $54^{\circ}$ and $55^{\circ} \mathrm{N}$, there occurred at

\begin{tabular}{|c|c|c|c|}
\hline & thoms & & pecie \\
\hline 100 & , & 13 & , \\
\hline 200 & , & 14 & , \\
\hline 00 & ” & 20 & " \\
\hline 00 & ", & 22 & " \\
\hline 500 & " & 7 & " \\
\hline
\end{tabular}
600 fathoms, 12 species.

$\begin{array}{rrrr}700 & , & 9 & \\ 800 & \prime & 10 & \\ 1,000 & " & 9 & " \\ 1,200 & " & 9 & \end{array}$

Between $55^{\circ}$ and $56^{\circ} \mathrm{N}$. there occurred at

\begin{tabular}{ccrl}
0 fathoms, & \multicolumn{2}{c}{ species. } \\
100 & 6 & & \\
200 & $\prime$ & 10 & $"$ \\
400 & $\prime$ & 12 & \\
500 & $"$ & 18 &
\end{tabular}

600 fathoms, 8 species.

$\begin{array}{rlll}700 \quad & 8 & \\ 800 \quad & 6 & 6 \\ 1,000 \quad & 8 & 8\end{array}$


Between $56^{\circ}$ and $57^{\circ} \mathrm{N}$. there occurred at

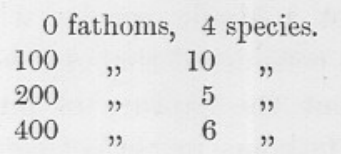

\begin{tabular}{|c|c|c|}
\hline \multicolumn{3}{|c|}{500 fathoms, 11} \\
\hline 600 & $"$ & 4 \\
\hline 700 & $"$ & 5 \\
\hline 800 & " & 6 \\
\hline
\end{tabular}

Between $58^{\circ}$ and $59^{\circ} \mathrm{N}$. there occurred at

\begin{tabular}{l|l}
0 fathoms, 2 species. & 200 fathoms, 8 species. \\
$100 " 11 "$ & $300 " 8 \%$
\end{tabular}

Between $59^{\circ}$ and $60^{\circ} \mathrm{N}$. there occurred at

\begin{tabular}{|c|c|c|c|c|c|}
\hline \multicolumn{2}{|c|}{0 fathoms, } & 3 species. & 400 & homs, & 5 species. \\
\hline 100 & " & 8, & 500 & $"$ & 4 \\
\hline 200 & $"$ & $"$ & 600 & " & 5 \\
\hline 300 & $"$ & 15 & 800 & $"$ & 4 \\
\hline
\end{tabular}

Between $60^{\circ}$ and $61^{\circ} \mathrm{N}$. there occurred in the warm area (F. v., F. vI.) at $\begin{array}{ll}0 \text { fathoms, } & 2 \text { species. } \\ 100 " & 4 \Rightarrow\end{array}$

Between $60^{\circ}$ and $61^{\circ}$ N. there occurred in the cold area (F. viI., F. viII., F. IX.) at

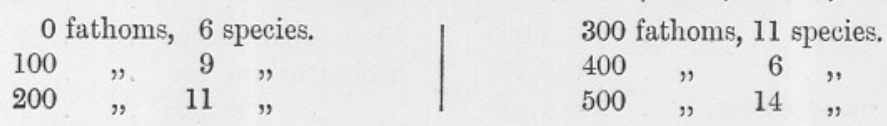

It is not unfair to conclude from these data that the greater number of species of Copepoda in the North Atlantic prefer a mesoplanktonic existence between $200-500$ or 600 fathoms depth; and that this is also the case in the "cold area" of the Faröe Channel.

At Station A 2, June, 1901, there were taken at

\begin{tabular}{lrl|l}
0 fathoms, & 6 species. & 400 fathoms, 14 species. \\
100 & 5 & &
\end{tabular}

At Station A 2, July, 1901, there were taken at

\begin{tabular}{cl|l}
0 fathoms, & 3 species. & 200 fathoms, 9 species. \\
$100 " 6 "$ & $600 \%$
\end{tabular}

At 400 and 500 fathoms there was an abundance of Copepoda, much more than from 200 fathoms to the surface.

At Station A 2, June, 1902, there were taken at 100 fathoms, 11 species.

200 " 8 " 400-200 fathoms, 13 species. 
When the Copepod species of the warm area of the North Atlantic are examined it is seen that there is not a single species which is purely epiplanktonic. For long it has been considered that Anomalocera Patersoni was a purely surface species, but the capture of an adult male example in a bottom scraping at 400 fathoms, in perfect condition, shows that it can sometimes descend to considerable depths.

Longipedia coronata, an Harpacticid of supposed purely littoral habit, is shown also to exist at great depths, having been taken in scrapings of the bottom at 400 and 500 fathoms respectively.

\section{The Vertical Range of Species in the North Atlantic (excluding the Faröe Channel cold area).*}

\begin{tabular}{|c|c|c|c|c|}
\hline \multirow{4}{*}{$\begin{array}{l}\text { Calanus finmarchicus } \\
" \quad \text { tenuicornis . } \\
\text { Eucalanus elongatus. } \\
,, \quad \text { crassus. }\end{array}$} & $\begin{array}{l}\text { Fathoms. } \\
0-1,200\end{array}$ & Oithona species & & $\begin{array}{l}\text { Fathoms. } \\
0-1,200\end{array}$ \\
\hline & 500 & Gaetanus sp. $\uparrow$ & & . $200-400$ \\
\hline & $0-500$ & Gaidius sp. & & . $300-400$ \\
\hline & $100-500$ & Spinocalanus sp. & & . $300-1,000$ \\
\hline hincalanus nasutus & $0-1,000$ & Pseudætideus armatu & & . $200-60$ \\
\hline racalanus parvus & $0-1$, & us bidentatus & & . $200-70$ \\
\hline eudocalanus elongatus & 0 & Egisthus . & & 300 \\
\hline artia Clausii & $0-1$, & Bradyidus armatus & . & . $400-50$ \\
\hline . & & Scolecithrix minor & . & . $100-30$ \\
\hline ma atlas & 0 &,$\quad$ similis & & . $100-20$ \\
\hline Griula inc & & atlantice & & . 3 \\
\hline " Nor & $300-8$ & Amallophora magna & & . 300 \\
\hline lon & -4 & Lophothrix secu & & 300 \\
\hline ta nor & $-1,000$ & fror & & \\
\hline 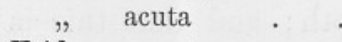 & 3 & Faroella multiserrata & & $200-1,00$ \\
\hline r & $100-700$ & Undeuchæta major & $r$ and & \\
\hline lamma robusta & 200-1, & $\min$ & & . 30 \\
\hline abdominale & 200 & tilus sp. & . & . $300-500$ \\
\hline terochæta vipera . & 200 & Candace norvegica & & . $300-50$ \\
\hline longicornis & 300 & rotunda & & . 300 \\
\hline - norvegica & $100-1$ & $\mathrm{Me}$ & . & . 60 \\
\hline hibernica & 400 & us sp. & & $300-400$ \\
\hline grandis & 700 & Euchirella carinata $\ddagger$ & & . $100-40$ \\
\hline loptilus long & $100-20 c$ & " curticaud & & 300 \\
\hline act & $200-30$ & Paraugaptilus & & \\
\hline cicutia flavic & $200-500$ & coronata & & $300-500$ \\
\hline $\begin{array}{l}\text { grandis } \\
\text { enna spinifera }\end{array}$ & $\begin{array}{l}700 \\
100-40\end{array}$ & Anomalocera Paterso & & 0 \\
\hline
\end{tabular}

* The depth in fathoms here given is only the extreme range above and below at which the species were taken.

† Young examples only at 200 fathoms.

‡ Young examples only at 100 fathoms. 
Tables showing the depths at which the different species of Copepoda were taken in the Closing Net.

In the following tables $\mathrm{j}$ signifies young specimen. The temperatures at each of these stations will be published subsequently along with the salinities.

TABLE I.

Faröe Channel Cold Area.

Station F vII. $\quad 61^{\circ} 1^{\prime} \quad$ N., $7^{\circ} 42^{\prime}$ W. -460 f. ; August 13, 1903. " F virl. $60^{\circ} 30^{\prime} \mathrm{N} ., 7^{\circ} 47^{\prime}$ W. $-547 \mathrm{f}$; ; " 14,

\begin{tabular}{|c|c|c|c|c|c|c|c|}
\hline Depth in fathoms. & ing net. & 0 & 100 & 200 & 300 & 400 & 500 \\
\hline Calanus finmarchicus & . & $x$ & $x$ & $x$ & $x$ & - & - \\
\hline ,, hyperboreus & . & - & - & $x$ & $x$ & $x$ & $x$ \\
\hline Eucalanus elongatus & • & - & - & - & - & - & $x$ \\
\hline Pseudocalanus elongatus & - & - & $x$ & $x$ & - & - & $x$ \\
\hline Paracalanus parvus . & - & - & - & $x$ & - & $x$ & $x$ \\
\hline Rhincalanus nasutus & - & - & $x$ & $x$ & - & - & $x$ \\
\hline Metridia lucens. & . & $x$ & $x$ & $x$ & - & - & $x$ \\
\hline longa . & • & - & - & $x$ & - & $x$ & - \\
\hline 环ideus armatus & . & - & $x$ & $x$ & $x$ & - & $x$ \\
\hline Euchæta norvegica & . & - & - & - & $x$ & $x$ & $x$ \\
\hline Gaidius pungens. & . & - & - & - & $x$ & - & $\mathrm{x}$ \\
\hline Temora longicornis & . & $x$ & - & - & - & - & $x$ \\
\hline Pleuromamma robusta & . & - & - & $\times$ & $x$ & - & $x$ \\
\hline Acartia Clausii : & . & $x$ & $x$ & $x$ & - & $x$ & $x$ \\
\hline Gaetanus caudani & . & - & - & - & $x$ & - & - \\
\hline Lophothrix securifrons. & - & - & - & - & $x$ & - & - \\
\hline Heterorhabdus norvegicu & - & - & - & - & $x$ & - & - \\
\hline Scolecithrix minor & . & - & $\times$ & - & - & - & - \\
\hline Ectinosoma atlantica & - & $x$ & $x$ & - & - & - & - \\
\hline Oithona sp. & . & $x$ & - & $x$ & $x$ & - & $x$ \\
\hline Oncea sp. & - & - & $x$ & - & $x$ & $x$ & $x$ \\
\hline
\end{tabular}

TABLE II.

Between $60^{\circ}-61^{\circ} \mathrm{N}$. Stations F v, and F vi. F v. $60^{\circ} 29^{\prime}$ N., $9^{\circ} 30^{\prime}$ W. -194 f.; August 8,1903 .

F vi. $60^{\circ} 41^{\prime}$ N., $8^{\circ} 50^{\prime}$ W. -75 f. ; " 9 " (Faröe Bank).

\begin{tabular}{|c|c|c|c|c|}
\hline Depth in fathoms. & Closing net. & 0 & 100 & 200 \\
\hline Calanus finmarchicus & $\mathrm{s}$ & - & $x$ & $x$ \\
\hline ," hyperboreus & . & - & - & $x$ \\
\hline Metridia lucens. & . & - & $x$ & $x$ \\
\hline , longa. & . & - & - & $x$ \\
\hline Euchæta norvegica & . & - & - & $\times \mathrm{j}$ \\
\hline Acartia Clausii . & . & $x$ & $x$ & $x$ \\
\hline Candace norvegica & . & - & - & $x$ \\
\hline Oithona sp. & . & $\mathrm{x}$ & $x$ & $x$ \\
\hline
\end{tabular}


TABLE III.

Between $59^{\circ}-60^{\circ} \mathrm{N}$. Stations F III. and F IV.

F III. $59^{\circ} 18^{\prime}$ N., $8^{\circ} 80^{\prime}$ W. -840 f. ; August 6, 1903.

F rv. $59^{\circ} 54^{\prime}$ N., $8^{\circ} 42^{\prime}$ W. -720 f.;

\begin{tabular}{|c|c|c|c|c|c|c|c|c|c|c|}
\hline Depth in fathom & ms. & Closing net. & 0 & 100 & 200 & 300 & 400 & 500 & 600 & 800 \\
\hline Calanus finmarchicus & . & . & - & $x$ & - & - & $x$ & $x$ & $x$ & $x$ \\
\hline Rhincalanus nasutus & . & . & - & - & - & - & - & - & - & $x$ \\
\hline Megacalanus princeps & . & . & - & - & - & - & - & $x$ & - & - \\
\hline Paracalanus parvus & - & - & - & $x$ & $x$ & - & - & - & - & - \\
\hline Acartia Clausii & - & - & $x$ & $x$ & $x$ & - & - & - & - & $\times$ \\
\hline Ectinosoma atlantica & . & - & - & - & $x$ & - & - & - & - & - \\
\hline Pseudætidius armatus & . & . & - & - & - & $x$ & - & - & - & - \\
\hline Faroella multiserrata & - & . & - & - & - & $x$ & - & - & $x$ & - \\
\hline Metridia lucens & . & . & $x$ & $x$ & - & - & - & - & - & - \\
\hline ,, longa & . & . & - & $x$ & - & - & - & - & - & - \\
\hline Normani & - & - & - & - & - & $x$ & - & - & - & - \\
\hline brevicauda & $\therefore$ & . & - & - & - & $x$ & - & $x$ & - & - \\
\hline Heterorhabdus norvegi & icus & . & - & - & - & - & - & - & $x$ & $x$ \\
\hline longico & ornis & . & - & - & - & $x$ & $x$ & - & - & - \\
\hline Pleuromamma robusta & & . & - & - & - & $x$ & - & - & $x$ & - \\
\hline Lucicutia flavicornis & . & . & - & - & - & $x$ & - & - & - & - \\
\hline Euchæta norvegica & . & . & - & - & - & $x$ & $x$ & - & - & - \\
\hline Gaetanus armiger & . & · & - & - & - & $x$ & - & - & - & - \\
\hline Candace norvegica & . & . & - & $x$ & - & $x$ & - & - & - & - \\
\hline Amallophora magna & . & . & - & - & - & $x$ & - & - & - & - \\
\hline Augaptilus longicaudat & tus & . & - & - & - & $x$ & - & - & - & - \\
\hline ," magnus & - & - & - & - & - & $x$ & - & - & - & - \\
\hline Paraugaptilus & - & $\cdot$ & - & - & - & $x$ & - & - & - & - \\
\hline Spinocalanus magnus & - & • & - & - & - & $x$ & - & - & - & - \\
\hline Oithona sp. & - & · & $x$ & $x$ & $x$ & - & $x$ & - & - & - \\
\hline Oncea sp. & - & - & - & $x$ & $x$ & - & $x$ & $x$ & $x$ & - \\
\hline
\end{tabular}

TABLE IV.

Between $58^{\circ}$ and $59^{\circ}$-Stations F I, and FII.

F I. $58^{\circ} 24^{\prime}$ N., $8^{\circ} 30^{\prime}$ W. -110 f. ; Aug. 4, 1903.

F II. $58^{\circ} 45^{\prime}$ N., $8^{\circ} 35^{\prime}$ W. -340 f. ; , 5 ,

\begin{tabular}{|c|c|c|c|c|c|c|}
\hline Depth in fathoms. & Closin & & 0 & 100 & 200 & 300 \\
\hline \multicolumn{2}{|c|}{ Calanus finmarchicus } & - & - & $x$ & $x$ & $x$ \\
\hline \multicolumn{2}{|c|}{ Eucalanus elongatus } & - & - & $x$ & - & . \\
\hline \multicolumn{2}{|c|}{ Rhincalanus nasutus } & - & - & $x$ & - & - \\
\hline \multicolumn{2}{|c|}{ Paracalanus parvus } & . & - & $x$ & - & \\
\hline \multicolumn{2}{|c|}{ Ætideus armatus . } & . & - & $x$ & $x$ & - \\
\hline Acartia Clausii & • & . & $\times$ & $x$ & - & $x$ \\
\hline Scolecithrix minor & $\mathrm{r}$. & - & - & $\times$ & - & - \\
\hline Euchæta norvegica & a. & . & - & $\times \mathrm{j}$ & $x$ & $x$ \\
\hline \multicolumn{2}{|c|}{ Pleuromamma robusta } & . & - & - & $x$ & $x$ \\
\hline \multirow{2}{*}{\multicolumn{2}{|c|}{$\begin{array}{c}\text { Metridia lucens } \\
\text {, brevicauda. }\end{array}$}} & - & - & $\times$ & $\times$ & - \\
\hline & & . & - & - & $x$ & $x$ \\
\hline \multicolumn{2}{|c|}{ Augaptilus magnus. } & · & - & - & - & $x$ \\
\hline \multirow{2}{*}{\multicolumn{2}{|c|}{$\begin{array}{l}\text { Oithona sp. } \\
\text { Oncea sp. }\end{array}$}} & - & $x$ & $x$ & $x$ & $x$ \\
\hline & & - & - & $x$ & $x$ & $x$ \\
\hline
\end{tabular}


TABLE V.

Between $56^{\circ}-57^{\circ}$. Stations E 17 and E 18 .

E 17 . $56^{\circ} 11^{\prime}$ N., $9^{\circ} 50^{\prime}$ W. -875 f. ; July $15,1903$.

E $18.56^{\circ} 37^{\prime}$ N., $9^{\circ} 48^{\prime}$ W. $-912 \mathrm{f}$.

\begin{tabular}{|c|c|c|c|c|c|c|c|c|c|c|}
\hline Depth in fathoms. & & Closing net. & 0 & 100 & 200 & 400 & 500 & 600 & 700 & 800 \\
\hline Calanus finmarchicus & . & . & - & $x$ & $x$ & $x$ & $x$ & - & $x$ & $x$ \\
\hline Eucalanus elongatus & . & . & - & - & - & - & $x$ & - & - & - \\
\hline ,, crassus & . & . & - & - & $x$ & - & - & - & - & - \\
\hline Rhincalanus nasutus & . & . & - & $x$ & - & - & - & - & - & $x$ \\
\hline Paracalanus parvus & . & . & $x$ & - & - & - & $x$ & - & - & - \\
\hline Pseudocalanus elongatu & us & . & $x$ & $x$ & - & - & - & - & - & - \\
\hline Acartia Clausii & . & . & $x$ & $x$ & - & - & $x$ & $x$ & - & $x$ \\
\hline Etideus armatus & . & . & - & $x$ & - & - & - & - & - & - \\
\hline Scolecithrix minor & . & . & - & $x$ & - & - & - & - & - & - \\
\hline Spinocalanus magnus & . & . & - & - & - & $x$ & $x$ & - & - & - \\
\hline Metridia lucens & . & . & $x$ & $x$ & $x$ & $x$ & $x$ & $x$ & $x$ & $x$ \\
\hline Normani & - & . & - & - & - & $x$ & - & - & -1 & - \\
\hline Pseudætideus armatus & & . & - & - & - & $x$ & $x$ & - & - & - \\
\hline Euchæta norvegica & & - & - & $x$ & - & - & $x$ & - & $x$ & - \\
\hline Heterorhabdus grandis & & . & - & - & - & - & - & - & $x$ & - \\
\hline Ectinosoma atlantica & . & . & - & - & - & - & - & - & - & $x$ \\
\hline Candace norvegica & . & . & - & - & - & - & $x$ & - & - & - \\
\hline Lucicutia flavicornis & . & . & - & - & - & - & $x$ & - & - & - \\
\hline Oithona sp. & . & . & - & $x$ & $x$ & $x$ & - & $x$ & - & - \\
\hline Oncea sp. & . & . & - & $x$ & $x$ & - & $x$ & $x$ & $x$ & $x$ \\
\hline
\end{tabular}

\section{TABLE VI.}

Between $55^{\circ}$ and $56^{\circ}$-Stations E 14 , E 15 , E 16.

E 14. $55^{\circ} 00^{\prime}$ N., $12^{\circ} 00^{\prime}$ W. $-1,577$ f. ; July 12 , 1903.

E15. $55^{\circ} 47^{\prime}$ N., $12^{\circ} 28^{\prime}$ W. $-1,561$ f. ; , 16

E 16. $55^{\circ} 47^{\prime}$ N., $10^{\circ} 12^{\prime}$ W. $-1,325$ f. ; , 19 ,

\begin{tabular}{|c|c|c|c|c|c|c|c|c|c|c|c|}
\hline Depth in fathoms. $\mathrm{Cl}$ & Closing & net. & 0 & 100 & 200 & 400 & 500 & 600 & 700 & 800 & 1,000 \\
\hline \multirow{4}{*}{$\begin{array}{l}\text { Calanus finmarchicus } \\
\text {," tenuicornis } \\
\text { Rhincalanus nasutus } \\
\text { Eucalanus elongatus }\end{array}$} & . & . & - & $x$ & - & $x$ & $x$ & - & - & $x$ & $x$ \\
\hline & - & . & - & - & - & - & $x$ & - & - & - & - \\
\hline & . & - & - & - & - & - & $x$ & - & $x$ & - & $\times$ \\
\hline & - & - & - & - & - & $\times$ & $x$ & - & - & - & - \\
\hline \multirow{2}{*}{ Metridia lucens } & - & . & - & - & $\times \mathrm{j}$ & $x$ & $x$ & - & - & - & - \\
\hline & - & $\because$ & $x$ & $x$ & $x^{0}$ & $x$ & $x$ & - & $x$ & $x$ & $x$ \\
\hline \multirow{2}{*}{$\begin{array}{l}\text { Norman } \\
\text { longa. }\end{array}$} & - & - & - & - & - & - & $x$ & $\times$ & - & - & - \\
\hline & - & - & - & - & $\times$ & - & $\times$ & - & - & - & - \\
\hline 玵ideus armatus & - & - & - & $\times$ & $\times$ & - & - & - & $x$ & - & - \\
\hline Acartia Clausii . & - & . & $x$ & $\times$ & - & $x$ & $x$ & $x$ & $x$ & $x$ & $x$ \\
\hline \multirow{2}{*}{$\begin{array}{l}\text { Ectinosoma atlantica } \\
\text { Gaetanus armiger }\end{array}$} & . & - & - & - & - & $\times$ & $x$ & - & $x$ & - & - \\
\hline & . & . & - & - & $\times \mathrm{j}$ & - & $x$ & - & - & - & - \\
\hline Gaetanus armiger & - & . & - & - & - & $x$ & - & - & - & - & - \\
\hline $\begin{array}{ll}, & \text { major } \\
, & \text { caudani }\end{array}$ & - & - & - & - & $x$ & - & - & - & - & - & - \\
\hline Gaidius pungens & . & . & - & - & - & - & $x$ & - & - & - & - \\
\hline \multirow{2}{*}{$\begin{array}{l}\text { Euchæta norvegica } \\
\text { barbata }\end{array}$} & . & . & - & $\times \mathrm{j}$ & - & - & - & $x$ & - & - & - \\
\hline & $\therefore$ & - & - & - & - & - & $x$ & - & - & - & - \\
\hline \multirow{2}{*}{\multicolumn{2}{|c|}{$\begin{array}{l}\text { Heterorhabdus norvegicus } \\
\text { grandis }\end{array}$}} & - & - & - & $x$ & - & - & $x$ & - & - & - \\
\hline & & . & - & - & - & $x$ & - & - & - & - & - \\
\hline \multicolumn{2}{|c|}{ Pseudætideus armatus . } & - & - & - & - & - & - & $x$ & - & - & - \\
\hline Lucicutia flavicornis & - & - & - & - & - & - & - & $x$ & - & - & - \\
\hline Euchirella carinata & - & . & - & - & - & - & $x$ & - & - & - & - \\
\hline Faroella multiserrata & - & - & - & - & - & - & - & - & - & - & $x$ \\
\hline Pleuromamma robusta & a. & . & $x$ & - & $x$ & - & $x$ & - & - & - & $x$ \\
\hline Scolecithrix minor & . & . & - & - & - & - & $x$ & - & - & - & - \\
\hline \multicolumn{2}{|c|}{ Xanthocalanus atlanticus } & . & - & - & - & $x$ & - & - & - & - & - \\
\hline \multirow{2}{*}{$\begin{array}{l}\text { Candace norvegica } \\
\text { Spinocalanus magnus }\end{array}$} & . & . & - & - & - & - & $x$ & - & - & - & - \\
\hline & • & . & - & - & - & $x$ & - & $x$ & $x$ & $\times$ & - \\
\hline \multirow{2}{*}{$\begin{array}{l}\text { Oncea sp. } \\
\text { Oithona sp. }\end{array}$} & . & . & - & - & $x$ & - & $x$ & $x$ & $x$ & $\times$ & $x$ \\
\hline & . & . & $x$ & $x$ & $x$ & $x$ & $x$ & - & $x$ & $x$ & $x$ \\
\hline
\end{tabular}


TABLE VII.

Between $54^{\circ}-55^{\prime}$ N. Stations E 12 and 13.

$\begin{array}{ll}\text { E } 12 . & 54^{\circ} 00^{\prime} \text { N., } 12^{\circ} 0^{\prime} \text { W. }-205 \mathrm{f} \text {; ; July } 9,1903 . \\ \text { E 13, } & 54^{\circ} 30^{\prime} \text { N., } 12^{\circ} 0^{\prime} \text { W. }-1,608 \text { f.; , } 11, "\end{array}$

Between $53^{\circ}-54^{\circ}$. $\quad$ Between $52^{\circ}-53^{\circ}$. Stations E 10 and 11 . Stations $\mathrm{E} 8$ and 9. E $10.53^{\circ} 00^{\prime} \mathrm{N} ., 11^{\circ} 56^{\prime}$ W. E $8.52^{\circ} 00^{\prime} \mathrm{N} ., 12^{\circ} 00^{\prime} \mathrm{W}$. -100 f.; July 8, 1903. -255 f.; July 8, 1903 . E 11. $53^{\circ} 30^{\prime} \mathrm{N} ., 12^{\circ} 00^{\prime} \mathrm{W}$. E $9.52^{\circ} 30^{\prime} \mathrm{N} ., 12^{\circ} 00^{\prime} \mathrm{W}$. -150 f.; July 9, 1903. -130 f.; July 8, 1903.

Depth in fathoms. Clusing net. 010020030040050060070080010001200

Calanus finmarchicus tenuicornis .

Eucalanus elongatus crassus

Rhincalanus nasutus

Paracalanus parvus .

Metridia lucens ", brevicauda. Normani

Scolecithrix minor

Acartia Clausii

Ectinosoma atlantica

Atideus armatus

Euchrta norvegica .

", longicornis

Gaidius pungens

Gaetanus armiger ," major caudani

Euchirella carinata .

Lucicutia flavicornis

Phyllopus bidentatus

abdominalis - $-\times-----\times-$

Haloptilus longicornis

Undeuchæta major .

,' minor.

Candace norvegica . , robusta

Pseudætideus armatus

Augaptilus longicaudatus .

Spinocalanus magnus

Oithona sp.

Oncea sp.

Pseudocalanus elongatus . - - - - - - - - -

Euchirella curticauda

Ctenocalanus vanus .

Calocalanus pavo

Longipedia coronata 
TABLE VIII.

Between $51^{\circ}$ and $52^{\circ}-$ Stations E 1, E 2, E 3, स 4, E 5, E 6, E 7 .

E 1. $51^{\circ} 56^{\prime} \mathrm{N} ., 11^{\circ} 21^{\prime} \mathrm{W} .-120 \mathrm{f}$; ; June 10, 1903.

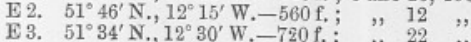

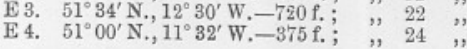

E 5. $51^{\circ} 00^{\prime} \mathrm{N} ., 12^{\circ} 00^{\prime} \mathrm{W} .-980 \mathrm{f}$.; June 25,1903 .

E 6. $50^{\circ} 56^{\prime} \mathrm{N}, 12^{\circ} 6^{\prime} \mathrm{W},-1,000 \mathrm{f}$,; July 6

Depth in fathoms. Closing net. $0 \quad 100 \quad 200 \quad 300 \quad 400 \quad 500$ 600 $700 \quad 800-1,000$

\begin{tabular}{lcccccccccccc}
\hline Calanus finmarchicus &. &. & $\times$ & $\times$ & - & $\times$ & $\times$ & $\times$ & $\times$ & $\times$ & $\times$ & -
\end{tabular}

Eucalanus elongatus

, crassus

Rhincalanus nasutus

Acartia Clausii

Ectinosoma atlantica

Metridia lucens

, brevicauda

, Normani

Heterorhabdus vipera

, abyssalis

Lucicutia flavicornis

Bradyidius armatus

Phyllopus bidentatus

Paracalanus parvus

Lucicutia grandis .

Anomalocera Patersoni

Ætideus armatus.

Pseudretidius armatus

Faroella

Euchæta norvegica

Phaenna spinifera

Haloptilus longicornis

$$
, \quad \text { acutifrons }
$$

Pseudocalanus elongatus.

Lophothrix frontalis

Spinocalanus magnus abyssalis

Augaptilus gibbus ,, longicaudata.

Scolecithrix magnus

Undeuchæta major

Gaetanus armiger

caudani

Amallophora magna

Xanthocalanus

', atlanticus .

thus atlanticus

Candace norvegica

Amallophora securifrons .

Pleuromamma robusta

Xanthocalanus cristatus .

Megacalanus

Oncea sp.

Oithona sp.

Longipedia coronata

$\begin{array}{ll}x & x \\ \times j & -\end{array}$

$-$

$\times$

$x$
$x$

$x$
$\times$
$x$

$\times \quad x$

$\times \times \times \times \times$




\section{EXPLANATION OF PLATE IX.}

1. Megacalanus, first foot, basal joints.

2.,$\quad$ third foot.

3. Eucalanus atlanticus, $\delta$, fifth feet.

$4 . \quad " \quad, \quad \delta$, mandible.

5. Scolecithrix similis, $q$, fifth foot.

$6 . \quad, \quad, \quad$, side view.

7. Gaetanus major, + , abdomen and last thoracic segment.

8. " ",$\quad$, first foot.

9. Ctenocalanus vanus, $\delta$, fifth feet.

10. Candace rotunda, $\uparrow$, dorsal view.

11. " ", क, fifth foot.

12. Lophothrix securifrons, + , dorsal view.

13. $", \quad$, , fifth feet.

14. $" \quad$ $\quad$ क distal portion of anterior foot-jaw.

15. " ", क, head.

16. Phyllopus bidentatus, $\delta$, fifth feet.

17. Xanthocalanus subagilis, $q$, fifth foot.

18. " $\quad$ cristatus, $q$, fifth foot.

19. " " $"$ क, head, dorsal view.

20. Gaetanus caudani, $\subsetneq$, dorsal view.

21. " $" \quad$, basal of fourth foot.

22. $", \quad$ क , first foot.

23. Chiridius Vanhöffeni, $\widetilde{\sigma}$, lateral view.

24. Xanthocalanus atlanticus, $q$, fifth foot.

25. " ,,$\quad$, second foot.

26. Faroella multiserrata, $q$, dorsal view.

27. " " $"$ क, posterior foot-jaw.

28. " " $\quad+$, terminal view of one of the feet.

29. Pseudætideus armatus, + , dorsal view.

30. " ",$\quad$, first foot.

31. " ",$\quad$, fifth feet.

32. Xanthocalanus subagilis, $\widetilde{\delta}$, fifth feet. $\quad 32 \alpha$. Terminal segment.

33. " $\quad$ atlanticus, $q$, lateral riew.

34. Heterorhabdus longicornis, $\delta$, fifth feet.

35 and $35 a$. Lucicutia magna, $\delta$, fifth feet.

36. Heterorhabdus grandis, $q$, fifth foot.

37. Lucicutia grandis, + , first foot.

38. " ",$\quad$, fifth foot.

39. Metridia Normani, $q$, fifth feet.

40. " $\quad$. $\quad$, portion of anterior antenna.

41. Lophothrix frontalis, $q$, head.

42. " " $"$ क, fifth foot.

43. Gaidius pungens, $\delta$, fifth feet.

44. Paraugaptilus Buchani, $\subsetneq$, abdomen.

45. " ",$\quad$ \&, fifth feet. 


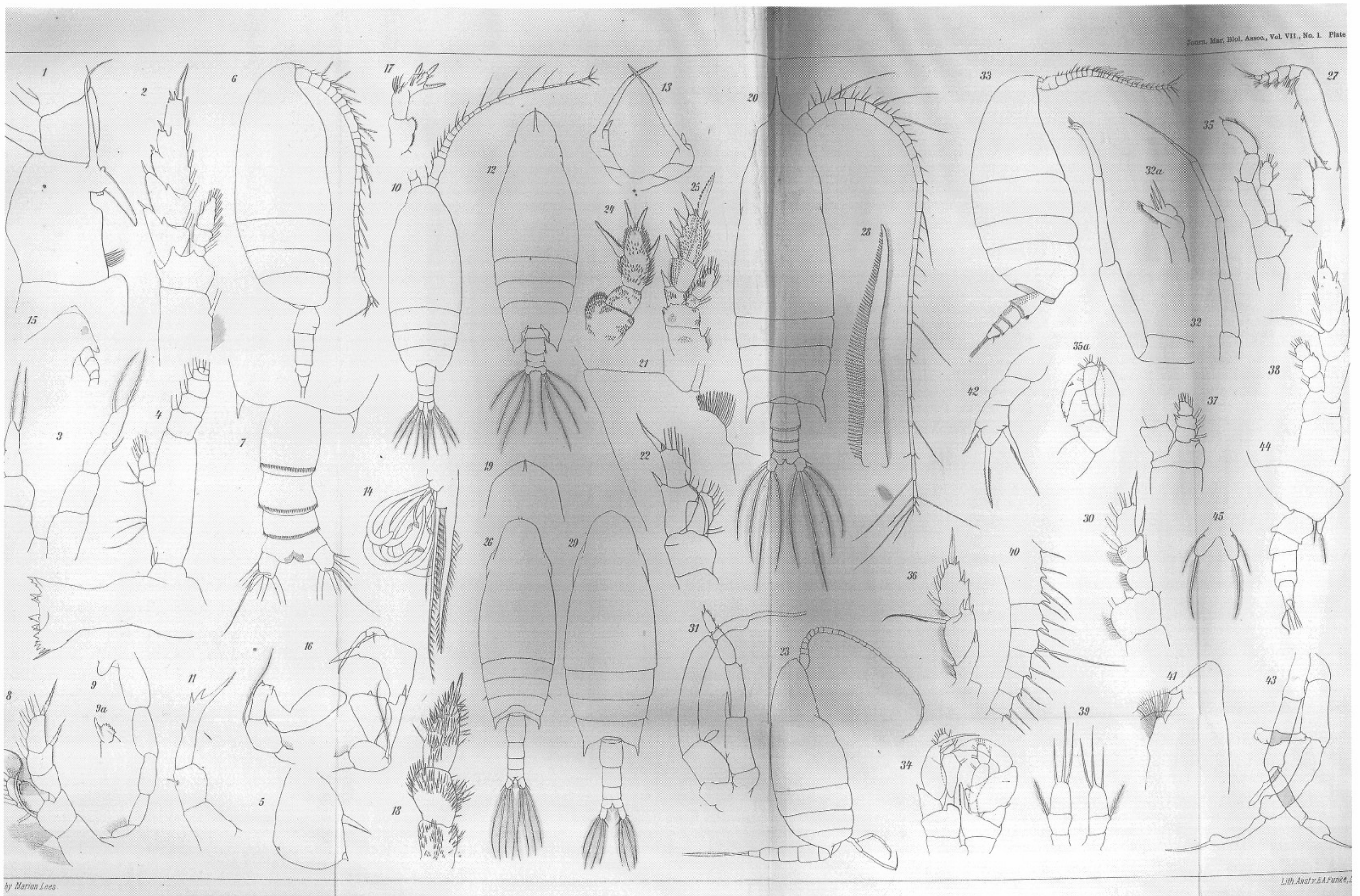

